\title{
Seasonal deposition processes and chronology of a varved Holocene lake sediment record from Chatyr Kol lake (Kyrgyz Republic)
}

\author{
Julia Kalanke ${ }^{1}$, Jens Mingram ${ }^{1}$, Stefan Lauterbach ${ }^{2}$, Ryskul Usubaliev $^{3}$, Rik Tjallingii ${ }^{1}$, and Achim Brauer ${ }^{1,4}$ \\ ${ }^{1}$ GFZ German Research Centre for Geosciences, Climate Dynamics and Landscape Evolution, Potsdam, Germany \\ ${ }^{2}$ University of Kiel, Leibniz Laboratory for Radiometric Dating and Stable Isotope Research, Kiel, Germany \\ ${ }^{3}$ Central Asian Institute for Applied Geoscience, Bishkek, Kyrgyzstan \\ ${ }^{4}$ University of Potsdam, Institute of Geoscience, Potsdam, Germany
}

Correspondence: Julia Kalanke (juliak@gfz-potsdam.de)

Received: 27 November 2019 - Discussion started: 20 January 2020

Revised: 21 April 2020 - Accepted: 8 May 2020 - Published: 24 June 2020

Abstract. Microfacies analysis of a sediment record from Chatyr Kol lake (Kyrgyz Republic) reveals the presence of seasonal laminae (varves) from the sediment base dated at $11619 \pm 603$ BP (years Before Present) up to $\sim 360 \pm 40$ BP. The Chatvd19 floating varve chronology relies on replicate varve counts on overlapping petrographic thin sections with an uncertainty of $\pm 5 \%$. The uppermost nonvarved interval was chronologically constrained by ${ }^{210} \mathrm{~Pb}$ and ${ }^{137} \mathrm{Cs}$ gamma spectrometry and interpolation based on varve thickness measurements of adjacent varved intervals with an assumed maximum uncertainty of $10 \%$. Six varve types were distinguished, are described in detail, and show a changing predominance of clastic-organic, clasticcalcitic or clastic-aragonitic, calcitic-clastic, organic-clastic, and clastic-diatom varves throughout the Holocene. Variations in varve thickness and the number and composition of seasonal sublayers are attributed to (1) changes in the amount of summer or winter/spring precipitation affecting local runoff and erosion and/or to (2) evaporative conditions during summer. Radiocarbon dating of bulk organic matter, daphnia remains, aquatic plant remains, and Ruppia maritima seeds reveals reservoir ages with a clear decreasing trend up core from $\sim 6150$ years in the early Holocene, to $\sim 3000$ years in the mid-Holocene, to $\sim 1000$ years and less in the late Holocene and modern times. In contrast, two radiocarbon dates from terrestrial plant remains are in good agreement with the varve-based chronology.

\section{Introduction}

The interplay of the large atmospheric circulation systems in Central Asia (CA), including the Siberian High, the westerlies, and the Indian Monsoon, and their influences on regional climate are still not fully understood. This is partly due to the large contrasts of landscapes (high mountains, deep basins, large water bodies, and deserts), the low spatial and temporal coverage of high-resolution palaeoclimate archives, and the partly problematic dating of these archives in this area. Information about Holocene climate variability in CA derives from several types of archives, including tree rings (Esper et al., 2003), speleothems (Fohlmeister et al., 2017; Wolff et al., 2017), ice cores (Aizen, 2004), aeolian deposits (Huayu et al., 2010), and lakes (Heinecke et al., 2017; Lauterbach et al., 2014; Mathis et al., 2014; Rasmussen et al., 2000; Ricketts et al., 2001; Schwarz et al., 2017). However, none of these lake records have reported annually laminated sediments. In Kyrgyzstan, varves have only been reported from Sary Chelek lake for the short time interval from $\sim 1940$ s to 2013 (Lauterbach et al., 2019). Other varved records in the wider region are from Telmen Lake in northern Mongolia, which includes discontinuous varved intervals during the last ca. 4390 cal BP (Peck et al., 2002) and from Sugan Lake in northwestern China covering the last $\sim 2670 \mathrm{BP}$ (Zhou et al., 2007). Deciphering Holocene climate changes based on limnic records in CA is challenging due to the influences of several factors: (1) chronological uncertainties caused by the scarcity of datable terrestrial plant material at high alti- 
tudes and often large ${ }^{14} \mathrm{C}$ reservoir effects of aquatic organic material (Hou et al., 2012; Lockot et al., 2016; Mischke et al., 2013); (2) human influence (Boomer et al., 2000; Mathis et al., 2014), possibly overprinting the natural climate signals in the archives; and (3) variations in the dominance of the mid-latitude westerlies, the Siberian High, and the Asian Monsoon system leading to different spatial and temporal climate effects over CA (Chen et al., 2008; Herzschuh, 2006; Mischke et al., 2017; Schroeter et al., 2020). All these factors can hamper data comparison and may lead to different palaeoenvironmental interpretations (Chen et al., 2008; Hou et al., 2012; Mischke et al., 2017). The investigation of varved lake sediments offers the unique opportunity for independent dating through varve counting. In addition, the description of varve micro-facies has the potential to provide detailed insights into environmental and climate variations at a seasonal scale. The sediment record from Chatyr Kol lake is the first varved record from CA covering most of the Holocene and the main goal of this study is to establish a robust age model through an integrated dating approach primarily based on varve counting. Varve counting requires an in-depth understanding of seasonal deposition of all varve types occurring in the sediment record. Therefore, we apply continuous micro-facies analysis for the entire sediment profile to describe the Holocene evolution of varve formation in detail and discuss fundamental deposition processes.

\section{Study site}

Chatyr Kol lake $\left(40^{\circ} 36^{\prime} \mathrm{N}, 75^{\circ} 14^{\prime} \mathrm{E}\right)$ (Fig. 1) is located at $\sim 3530 \mathrm{~m}$ above sea level (a.s.l.) in the intramontane Aksai Basin (De Grave et al., 2011; Koppes et al., 2008) in the southern Kyrgyz Republic. In the north, the basin is restricted by the At-Bashy Range and in the south by the Torugat mountain range, resulting in a catchment area of about $1084 \mathrm{~km}^{2}$. Geologically, the surrounding mountain ranges belong to Silurian to Carboniferous sedimentaryvolcanogenic complexes of marine-continental collision zones, consisting of limestones and dolomites, that crop out directly along the northern lakeshore, as well as siliceous rocks, shales, and scattered Permian granites that crop out in the south and north-east (Academy of Science of the Kyrgyz SSR, 1987). The modern lake, which has a maximum length of $23 \mathrm{~km}$, a width of $10 \mathrm{~km}$, and a maximum depth of $20 \mathrm{~m}$ in its western-central part, is endorheic and separated from the neighbouring Arpa river basin in the northwest by a moraine (Shnitnikov et al., 1978). The moraine originates from glacial advances of unknown age from the western Torugat mountain range. Present-day glaciers exist above $\sim 4000 \mathrm{~m}$ a.s.l. on the Torugat and At-Bashy mountain ranges, but only some of the At-Bashy glaciers drain into Chatyr Kol via the Kegagyr River. The lake further receives convective rainfall in summer (Aizen et al., 2001). A shallow dam at $\sim 3550 \mathrm{~m}$ a.s.l. hinders outflow to the east. Modern climate conditions are generally dry and mainly controlled by the westerlies and the Siberian Anticyclone Circulation (Aizen et al., 2001; Koppes et al., 2008). Mean annual precipitation is $\sim 275 \mathrm{~mm} \mathrm{yr}^{-1}$ as indicated by Aizen et al. (2001) for the evaluation and spatial averaging of annual precipitation of historical records published by Hydrometeo Publishing (Reference Book of Climate USSR, Kyrgyz SSR, 1988). This is comparable to long-term instrumental data from nearby (about $50 \mathrm{~km}$ away) weather stations at comparable altitudes, where annual precipitation means are $237 \mathrm{~mm} \mathrm{yr}^{-1}$ (station Chatirkul; $40^{\circ} 6^{\prime} \mathrm{N}, 75^{\circ} 8^{\prime} \mathrm{E} ; 3540 \mathrm{~m}$ a.s.l, $1961-$ $1990 \mathrm{CE}$ ) and $294 \mathrm{~mm} \mathrm{yr}^{-1}$ (station Tian Shan; $41^{\circ} 9^{\prime} \mathrm{N}$, $78^{\circ} 2^{\prime}$ E; $3614 \mathrm{~m}$ a.s.l., 1930-2000 CE) (Williams and Konovalov, 2008). Monthly-mean temperatures range from -26.0 to $8.0^{\circ} \mathrm{C}$ (Koppes et al., 2008; Academy of Science of the Kyrgyz SSR, 1987) with means of $-5.4^{\circ} \mathrm{C}$ (station Chatirkul) and $-7.6^{\circ} \mathrm{C}$ (station Tian Shan) (Williams and Konovalov, 2008). The salinity of the lake water ranges from $1.06-1.15 \mathrm{~g} \mathrm{~L}^{-1}$ in the deeper western part of the lake to $0.24 \mathrm{~g} \mathrm{~L}^{-1}$ in the shallower eastern part near the inflow (Romanovsky, 2007). Measurements of oxygen concentrations (YSI Pro 6600 V2) during a field trip in July 2012 ranged from $\sim 6 \mathrm{mg} \mathrm{L}^{-1}$ at the water surface to $\sim 1 \mathrm{mg} \mathrm{L}^{-1}$ at $19 \mathrm{~m}$ depth with a clear oxygen minimum zone below $\sim 11 \mathrm{~m}$ depth (Fig. 2). Water surface and bottom water temperatures (YSI Castaway CTD) at $19 \mathrm{~m}$ depth reached 13.2 and $9.4^{\circ} \mathrm{C}$. Specific conductivity (CTD) ranged from $1902 \mu \mathrm{Scm}^{-1}$ at $19 \mathrm{~m}$ to $1825 \mu \mathrm{Scm}^{-1}$; $\mathrm{pH}$ was $\sim 9$ (YSI Pro $6600 \mathrm{~V} 2$ ). Secchi depth was about $4 \mathrm{~m}$. Nowadays, the lake is largely occupied by the amphipod Gammarus alius sp. nov. (Sidorov, 2012), and no fish live in the lake (Shnitnikov et al., 1978).

The permafrost level is located at a depth of $2.5-3 \mathrm{~m}$ in the littoral coast zones, and the lake is covered by ice from October to April (Shnitnikov et al., 1978). Modern permafrost thawing results in unstable shores visible at the Maloye lake located $<2 \mathrm{~km}$ to the south of Chatyr Kol (Fig. 1, photo) and the development of small ponds on the shallow south-western shore of this lake and Chatyr Kol lake during summer. Several terraces in the north, south, and east of the lake result from Pleistocene-Holocene lake level fluctuations (Shnitnikov et al., 1978). Vegetation around the lake is generally poor and represented by high alpine meadows (Shnitnikov et al., 1978; Taft et al., 2011).

\section{Methods}

\subsection{Coring and composite profile}

Five parallel cores each of 3 to $6 \mathrm{~m}$ length have been retrieved in 2012 from the deepest part of the lake $\left(40^{\circ} 36.37^{\prime} \mathrm{N}\right.$, $75^{\circ} 14.02^{\prime} \mathrm{E}$ ) by using an UWITEC piston corer (Fig. 1, Table 1). All cores were opened, split, and photographed at GFZ Potsdam, where they are archived in a cold store at $4{ }^{\circ} \mathrm{C}$. A continuous composite profile of $623.5 \mathrm{~cm}$ length (CHAT12) was established by correlating the individual, 


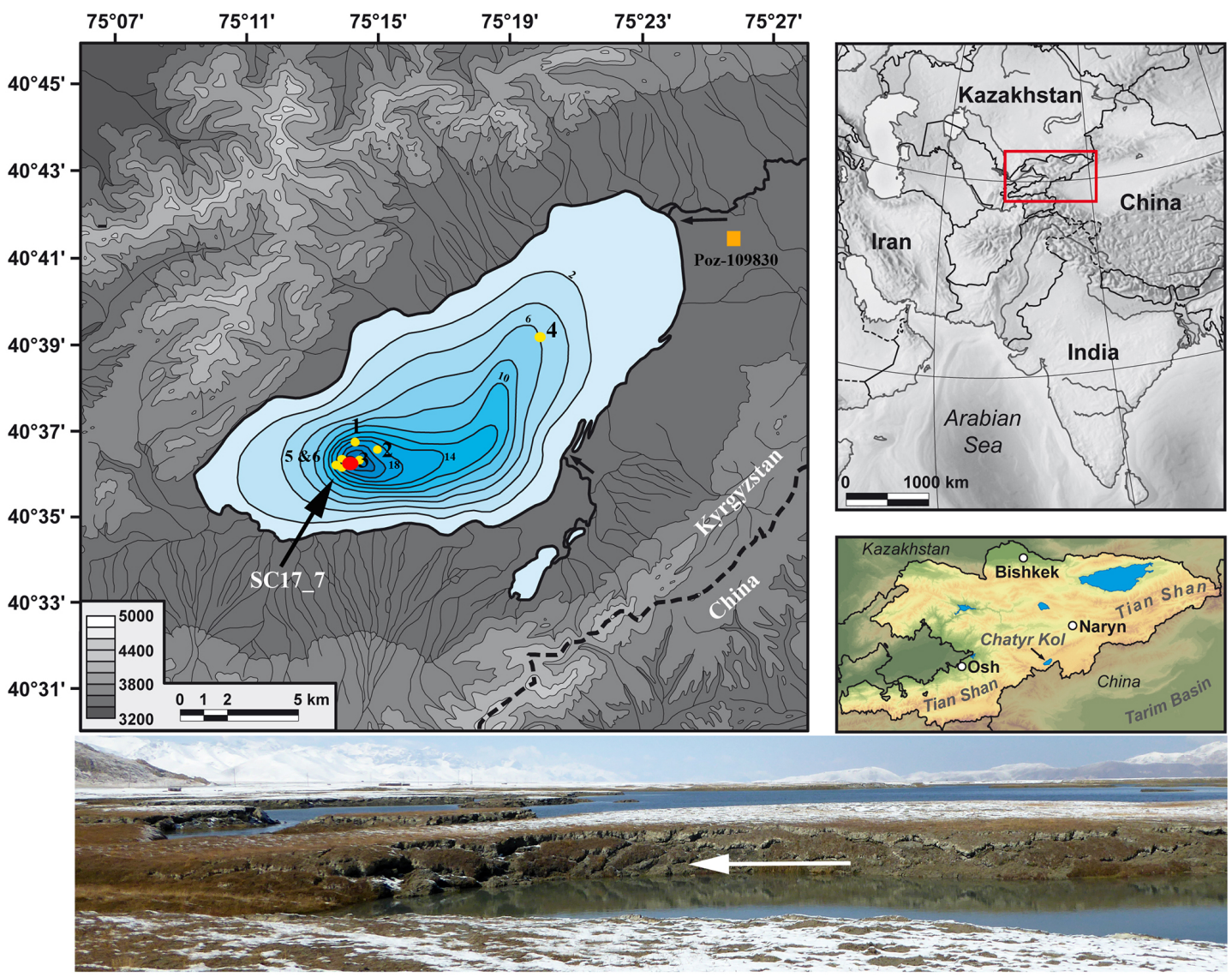

Figure 1. Location of Chatyr Kol lake, the composite profile (red dot), and the gravity cores (yellow dots). The orange square marks the location of ${ }^{14} \mathrm{C}$-dated leaves (Poz-109830, Table 2) found in the top of a mid-Holocene shoreline at $\sim 3540 \mathrm{~m}$ a.s.l. The relief map of Kyrgyzstan relies on the CGIAR-CSI SRTM $90 \mathrm{~m}(3 \mathrm{arcsec})$ digital elevation data (version 4) of the NASA Shuttle Radar Topography Mission (Jarvis, 2008). The figure was modified from Lauterbach et al. (2014). Photo of unstable shores (white arrow) of Maloye lake.
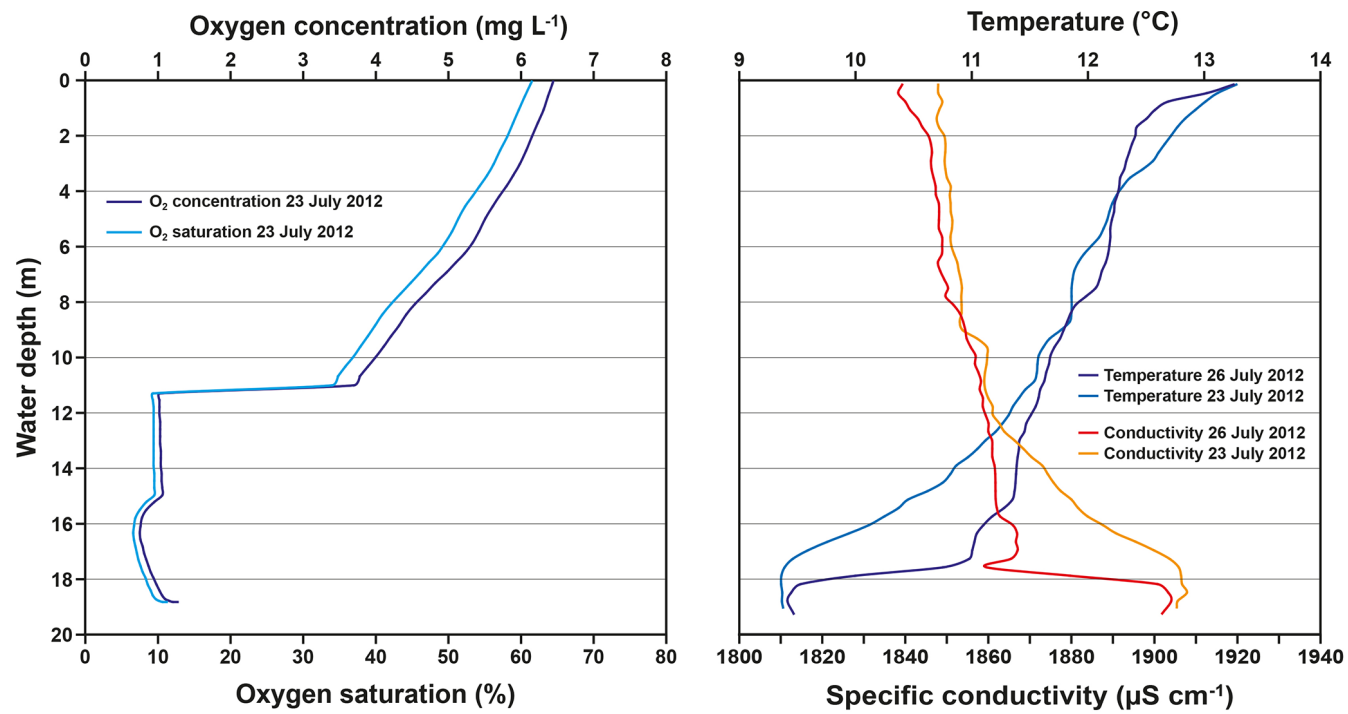

Figure 2. Oxygen concentration (YSI Pro 6600 V2), temperature, and specific conductivity measured with a CTD sensor during the field trip in 2012 at the core's location $\left(40^{\circ} 36.371^{\prime} \mathrm{N}, 75^{\circ} 14.006^{\prime} \mathrm{E}\right)$. 
Table 1. Coordinates of long and short cores.

\begin{tabular}{llll}
\hline Core ID & Latitude & Longitude & Depth $(\mathrm{m})$ \\
\hline CHAT12 & $40^{\circ} 36.370^{\prime}$ & $75^{\circ} 14.020^{\prime}$ & 20 \\
SC17_1 & $40^{\circ} 36.756^{\prime}$ & $75^{\circ} 14.481^{\prime}$ & 15.05 \\
SC17_2 & $40^{\circ} 36.587^{\prime}$ & $75^{\circ} 15.138^{\prime}$ & 17.25 \\
SC17_3 & $40^{\circ} 36.315^{\prime}$ & $75^{\circ} 14.577^{\prime}$ & 18.25 \\
SC17_4 & $40^{\circ} 39.124^{\prime}$ & $75^{\circ} 19.891^{\prime}$ & $5-10$ \\
SC17_5 & $40^{\circ} 36.363^{\prime}$ & $75^{\circ} 14.079^{\prime}$ & $19.5-20$ \\
SC17_6 & $40^{\circ} 36.213^{\prime}$ & $75^{\circ} 13.939^{\prime}$ & 19.2 \\
SC17_7 & $40^{\circ} 36.147^{\prime}$ & $75^{\circ} 14.062^{\prime}$ & 18.5 \\
\hline
\end{tabular}

overlapping cores via macroscopically visible marker layers (Fig. 3). Furthermore, seven parallel gravity cores (SC17_17) have been retrieved with a UWITEC gravity corer in 2017 (Fig. 1, Table 1) to recover the undisturbed sedimentwater interface, from which the best-preserved parallel core, SC17_7, was used for gamma spectrometric analysis.

\subsection{Sediment micro-facies analysis and varve counting}

Continuous $10 \mathrm{~cm}$ long sediment slabs with an overlap of $2 \mathrm{~cm}$ were taken from the whole composite profile to prepare large-scale petrographic thin sections. Thin section preparation followed the method described by Brauer and Casanova (2001) and included freeze-drying and vacuum impregnation of the sediment slabs with Araldite epoxy resin. Microfacies analysis, including a semiquantitative evaluation of planktic and periphytic diatoms, aquatic plant remains (e.g. Potamogeton sp., Ruppia maritima), ostracods, daphnia, characeae and chrysophytes, was carried out on a Zeiss Axioplan microscope using different magnifications $(25-400 \times)$ and included measurement of varve thicknesses, micro-facies/varve type characterization, the definition of varve boundaries, and the development of process-related deposition models. A varve quality index (VQI) ranging from 0 to 5 was given for each varve, which is comparable to the method from Żarczyński et al. (2018) and references therein.

- VQI 0 represents no varves or strongly disturbed varved sequences and no reliable counting (interpolation).

- VQI 1 represents very low varve preservation, horizontally discontinuous varve, less well-preserved sublayer boundaries, and difficult counting.

- VQI 2 represents low varve preservation, occasional horizontally discontinuous varve and sublayer boundaries, and reliable counting.

- VQI 3 represents medium varve preservation, horizontally continuous varve and sublayer boundaries, only small disturbances, and reliable counting.
- VQI 4 represents high varve preservation, clearly distinguishable varve and sublayer boundaries, and reliable counting.

- VQI 5 represents highest varve preservation, clearly distinguishable varve and sublayer boundaries, no disturbances, and reliable counting.

Varve counting was performed to establish a floating varve chronology. Non-varved intervals $(\mathrm{VQI}=0)$ between varved sediment sections were therefore interpolated by using the mean of sedimentation rates derived from about 20 varves above and below the non-varved part. Varves were counted twice by the same author. Counting uncertainty estimates were first assessed by the percentage deviation of the second to the first count within one thin section. The mean of these deviations was used as an overall counting uncertainty estimate and assigned to the entire varved record. The uncertainty estimates were thus also assigned to interpolated sequences.

\subsection{XRF element mapping}

$\mathrm{X}$-ray fluorescence (XRF) element mapping was performed on two selected Araldite impregnated sediment blocks (ca. $2 \mathrm{~cm} \times 10 \mathrm{~cm}$ ), which were prepared for thin sections used for the micro-facies analyses. XRF element mapping of these two sediment blocks allows for linking micro-facies analyses of typical varve types directly with geochemical sediment compositions. Element mapping was performed at $50 \mu \mathrm{m}$ resolution and covering most of the surface of the sediment block $(15 \mathrm{~mm} \times 100 \mathrm{~mm})$ using a Bruker M4 Tornado at GFZ Potsdam. This scanner is equipped with a $\mathrm{Rh} \mathrm{X}$-ray source operated at $50 \mathrm{kV}$ and $600 \mu \mathrm{A}$ in combination with polycapillary X-ray optics that irradiate a spot of $20 \mu \mathrm{m}$ for $50 \mathrm{~ms}$. After measuring and an initial spectrum deconvolution, normalized element intensities are used to visualize relative element abundances as $2 \mathrm{D}$ maps.

\subsection{Radiometric dating}

\subsubsection{Radiocarbon dating}

In total, 36 accelerator mass spectrometry (AMS) ${ }^{14} \mathrm{C}$ measurements were carried out at the Pozńan Radiocarbon Laboratory in Poland. Samples for ${ }^{14} \mathrm{C}$ measurements comprised two pieces of wood, bulk TOC (total organic carbon) samples, aquatic plant macro remains, daphnia remains, and Ruppia maritima seeds (Table 2). Additional samples of recent living daphnia and aquatic plants have been collected to assess the modern ${ }^{14} \mathrm{C}$ reservoir effect. The resulting conventional ${ }^{14} \mathrm{C}$ ages were calibrated using OxCal 4.3 (Ramsey, 2009) with the IntCal13 calibration curve (Reimer et al., 2013). 


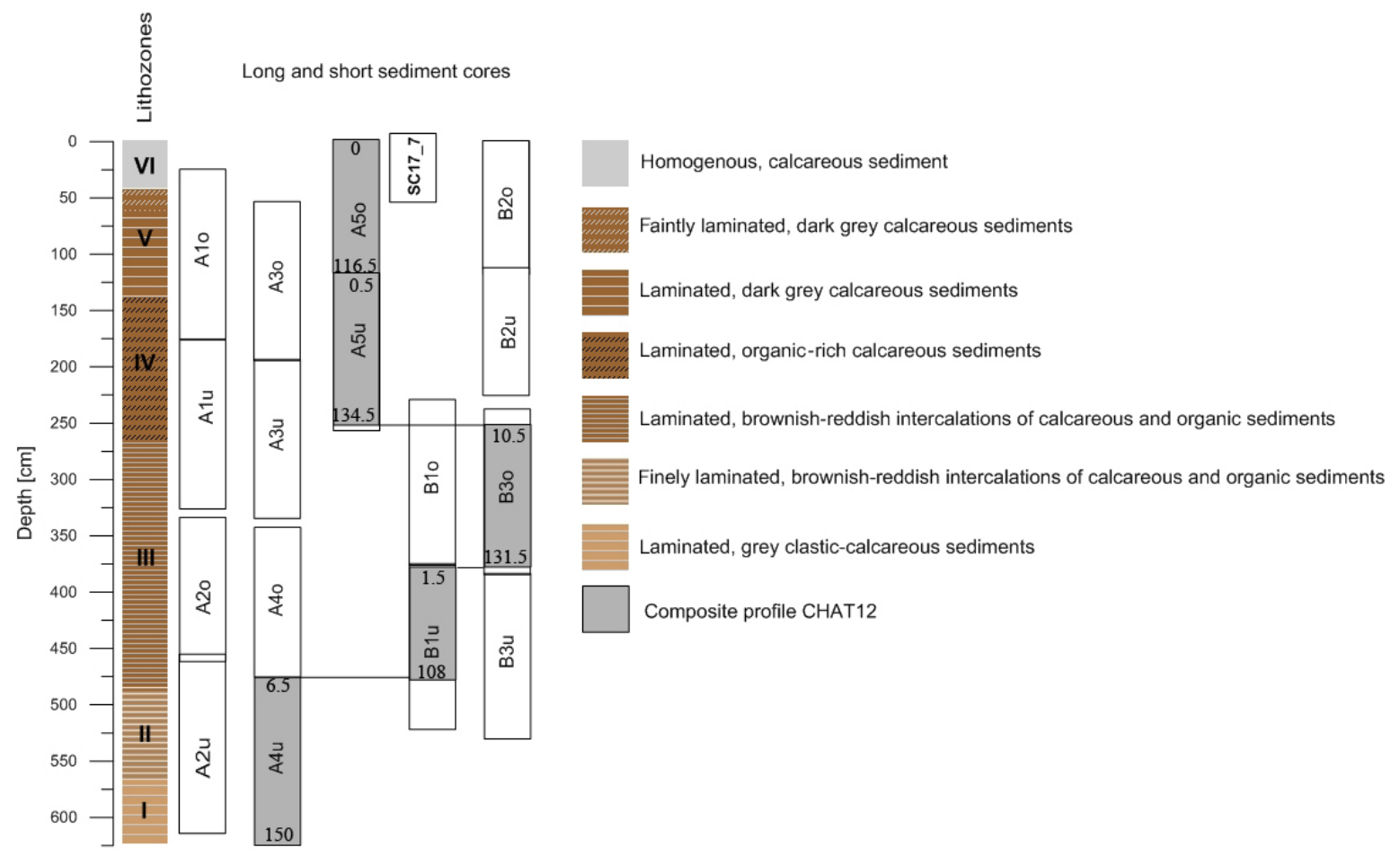

Figure 3. The composite profile CHAT12 (dark grey: piston cores A5o, A5u, B3o, B1u, and A4u; depth sections that were used are displayed within). Additional gravity cores taken in 2017 (SC17_1 to SC17_7) were only partly used for thin section preparation and gamma spectrometry dating. The gravity cores cover approximately the upper first metre of the composite profile.

\subsubsection{Gamma spectrometry dating}

Gamma spectrometry measurements were performed on $0.5 \mathrm{~cm}$ thick sediment slices that were continuously sampled from the upper $15.0 \mathrm{~cm}$ of gravity core SC17_7 (Supplement Table S1). The samples were freeze-dried and sieved through a $200 \mu \mathrm{m}$ mesh for homogenization and removal of larger plant particles. Individual sample-aliquots were filled into gas-tight sealable low-activity Kryal@ tubes at identical fill heights and accurately weighted. After sufficient ingrowth time, the gamma energies of ${ }^{210} \mathrm{~Pb}\left(T_{1 / 2}=22 \mathrm{yr}\right)$ and ${ }^{214} \mathrm{~Pb}\left(T_{1 / 2}=26.8 \mathrm{~min}\right)$, which is a daughter nuclide of ${ }^{222} \mathrm{Rn}\left(T_{1 / 2}=3.8 \mathrm{~d}\right)$, were measured at $46.54,295.24$, and $351.93 \mathrm{keV}$. In addition, the gamma energies of ${ }^{137} \mathrm{Cs}$ $\left(T_{1 / 2}=30.1 \mathrm{yr}\right)$ were measured at $661.66 \mathrm{keV}$. For this purpose, the Kryal@ tubes were placed into shielded measurement chambers equipped with two well-type germanium detectors, G1 and G2 (Canberra Industries), for $\sim 1.5$ to $7 \mathrm{~d}$ at GFZ Potsdam (Supplement Table S1) (Schettler et al., 2006). Hardware control, data storage, and spectrum analysis were realized with the software Genie 2000 (Canberra Industries). The average counting uncertainty was $5.9 \%$ for ${ }^{210} \mathrm{~Pb}$, $7.7 \%(295 \mathrm{keV})$ and $3.7 \%(351 \mathrm{keV})$ for ${ }^{214} \mathrm{~Pb}$, and $5.2 \%$ for ${ }^{137} \mathrm{Cs}$. Efficiency calibrations were carried out for ${ }^{210} \mathrm{~Pb}$, ${ }^{214} \mathrm{~Pb}$, and ${ }^{137} \mathrm{Cs}$ with the same analytical setup using an internal laboratory standard and the "Loess Nussloch" standard (Potts et al., 2003). Blank activities for ${ }^{137} \mathrm{Cs}$ were negligible, while average ${ }^{210} \mathrm{~Pb}$ blank activities of $10 \mathrm{mBq} \mathrm{g}^{-1}$ for detector $\mathrm{G} 2$ and ${ }^{214} \mathrm{~Pb}$ blank activities of $9 \mathrm{mBq} \mathrm{g}^{-1}$ for the detectors $\mathrm{G} 1$ and $\mathrm{G} 2$ were considered. The activity measurements of ${ }^{214} \mathrm{~Pb}$ were used to quantify the proportion of supported ${ }^{210} \mathrm{~Pb}\left({ }^{210} \mathrm{~Pb}_{\text {supp }}\right)$ produced by the decay of ${ }^{226} \mathrm{Ra}$ in the sediment. The activity of unsupported ${ }^{210} \mathrm{~Pb}\left({ }^{210} \mathrm{~Pb}\right.$ unsupp $)$ in the sediment, which originates from the decay of ${ }^{222} \mathrm{Rn}$ in the atmosphere and associated aeolian deposition, is quantified by the difference between measured ${ }^{210} \mathrm{~Pb}_{\text {total }}$ and ${ }^{210} \mathrm{~Pb}_{\text {supp }}$. We selected sections that showed linear correlations in the semi-logarithmic plot of ${ }^{210} \mathrm{~Pb}_{\text {unsupp versus depth to infer }}$ average sedimentation rates using the constant initial concentration (CIC) model (cf. Appleby, 2002) (Supplement Table S2). Intercalated sediment sections showed nearly uncorrelated $\ln \left({ }^{210} \mathrm{~Pb}_{\text {unsupp }}\right)$ vs. depth relationships at $10.25-9.25$, $6.25-4.25$, and $2.25-1.75 \mathrm{~cm}$ depths (Supplement Fig. S3). Therefore, the initial ${ }^{210} \mathrm{~Pb}_{\text {unsupp }}$ activities of samples that bridged these sections were used alternatively to determine time intervals between these samples to infer a chronology. To assess possible changes of the sedimentation regime, we additionally calculated sedimentation rates of each $0.5 \mathrm{~cm}$ thick sediment slice using the CRS model (constant initial ${ }^{210} \mathrm{~Pb}_{\text {unsupp }}$ supply) (cf. Appleby, 2002; Appleby and Oldfield, 1978) (Supplement Table S3). 
Table 2. ${ }^{14} \mathrm{C}$ dates (calibrated with $\mathrm{OxCal} 4.3$, IntCal13).

\begin{tabular}{|c|c|c|c|c|c|c|}
\hline Depth $(\mathrm{cm})$ & Lab ID & ${ }^{14} \mathrm{C}$ & Error & $\begin{array}{l}\text { cal BP }(95.4 \% \\
\text { probability range })\end{array}$ & $\begin{array}{l}\text { cal BP (midpoint + } \\
\text { span) }\end{array}$ & Material \\
\hline 0 & Poz-109830 & 5050 & 40 & $5664-5908$ & $5786 \pm 122$ & leaves \\
\hline 0 & Poz-54280 & 330 & 30 & $308-473$ & $391 \pm 83$ & recent aquatic plant \\
\hline 0 & Poz-54281 & 2425 & 25 & 2354-2692 & $2523 \pm 169$ & recent aquatic plant \\
\hline 0 & Poz-54279 & 225 & 30 & -4 to 310 & $155 \pm 155$ & recent Daphnia \\
\hline 38.5 & Poz-54282 & 755 & 35 & $660-735$ & $697 \pm 36$ & aquatic plant \\
\hline 41.5 & Poz-56609 & 1265 & 30 & 1088-1285 & $1187 \pm 98$ & bulk TOC \\
\hline 59.5 & Poz-54283 & 955 & 30 & $798-964$ & $881 \pm 83$ & aquatic plant \\
\hline 88 & Poz-54286 & 1595 & 30 & $1410-1549$ & $1480 \pm 69$ & aquatic plant \\
\hline 98 & Poz-54284 & 1715 & 35 & 1552-1706 & $1629 \pm 77$ & aquatic plant \\
\hline 98.7 & Poz-56614 & 1730 & 30 & 1564-1708 & $1636 \pm 72$ & aquatic plant \\
\hline 98.7 & Poz-556592 & 2220 & 30 & $2152-2324$ & $2238 \pm 86$ & bulk TOC \\
\hline 111 & Poz-54287 & 1925 & 30 & 1817-1947 & $1882 \pm 65$ & Daphnia remain \\
\hline 115.5 & Poz-54288 & 1960 & 30 & 1830-1989 & $1910 \pm 79$ & Daphnia remain \\
\hline 179.5 & Poz-56596 & 4150 & 35 & $4572-4827$ & $4700 \pm 128$ & bulk TOC \\
\hline 209.7 & Poz-56610 & 4930 & 35 & $5597-5727$ & $5662 \pm 65$ & bulk TOC \\
\hline 229.5 & Poz-54289 & 5790 & 50 & 6415-6665 & $6540 \pm 125$ & Daphnia remain \\
\hline 252 & Poz-56595 & 5840 & 40 & $6533-6747$ & $6640 \pm 107$ & bulk TOC \\
\hline 255.7 & Poz-54290 & 5880 & 35 & $6637-6785$ & $6659 \pm 126$ & Daphnia remain \\
\hline 299.7 & Poz-56593 & 6840 & 40 & 7591-7757 & $7674 \pm 83$ & bulk TOC \\
\hline 345 & Poz-56594 & 7610 & 40 & $8025-8180$ & $8103 \pm 78$ & bulk TOC \\
\hline 345 & Poz-54292 & 7305 & 35 & $8350-8514$ & $8432 \pm 82$ & bulk TOC \\
\hline 370.1 & Poz-56613 & 8200 & 50 & 9015-9300 & $9158 \pm 143$ & bulk TOC \\
\hline 380.5 & Poz-63307 & 5360 & 40 & $6003-6277$ & $6140 \pm 137$ & wood \\
\hline 391.4 & Poz-54294 & 8550 & 50 & $9465-9604$ & $9535 \pm 70$ & Daphnia remain \\
\hline 391.7 & Poz-54293 & 8710 & 50 & 9546-9887 & $9717 \pm 171$ & Daphnia remain \\
\hline 437.2 & Poz-54296 & 9160 & 50 & $10230-10487$ & $10359 \pm 129$ & Daphnia remain \\
\hline 439.9 & Poz-56611 & 9360 & 50 & $10427-10713$ & $10570 \pm 143$ & bulk TOC \\
\hline 466 & Poz-54297 & 9670 & 50 & $10789-11211$ & $11000 \pm 212$ & Daphnia remain \\
\hline 469 & Poz-54298 & 9690 & 50 & $10795-11226$ & $11011 \pm 216$ & Daphnia remain \\
\hline 508 & Poz-54299 & 10840 & 50 & $12681-12804$ & $12743 \pm 62$ & Ruppia maritima \\
\hline 510 & Poz-54300 & 11060 & 50 & $12790-13062$ & $12926 \pm 136$ & bulk TOC \\
\hline 528 & Poz-54301 & 12150 & 50 & $13831-14175$ & $14003 \pm 172$ & bulk TOC \\
\hline 528 & Poz-54302 & 8890 & 50 & $9785-10191$ & $9988 \pm 203$ & deciduous wood \\
\hline 549.5 & Poz-56591 & 12820 & 60 & $15105-15550$ & $15328 \pm 223$ & bulk TOC \\
\hline 571 & Poz-56608 & 13220 & 70 & $15660-16125$ & $15893 \pm 233$ & bulk TOC \\
\hline 585 & Poz-63308 & 14060 & 90 & $16759-17419$ & $17089 \pm 330$ & Ruppia maritima \\
\hline 620.5 & Poz-56590 & 13190 & 70 & $15612-16092$ & $15852 \pm 240$ & bulk TOC \\
\hline
\end{tabular}

\section{Results}

\subsection{Lithology}

The composite profile can be subdivided into six lithological units (Fig. 3). Lithozone I (LZ I) from 623.5 to $566.0 \mathrm{~cm}$ depth consists of greyish-brownish clastic-calcareous sediments. It shows millimetre-scale laminations of fine sandy and silty-to-clayey layers. LZ II $(566.0-480.0 \mathrm{~cm})$ exhibits intercalations between horizons of very fine millimetre-scale laminated brownish-reddish organic-rich sediments and sections with greyish calcareous sediments. Brownish-reddish intercalating horizons of millimetre-scale laminated organic and calcareous sediments characterize LZ III from 480.0 to
$273.0 \mathrm{~cm}$ depth. LZ IV $(273.0-130.0 \mathrm{~cm})$ is characterized by brownish-reddish millimetre-scale laminated organic-rich sediments with intercalated horizons rich in aquatic plant remains, which occur at 232.0-223.0, 185.0-180.0, and 164.0 $130.0 \mathrm{~cm}$ depths. LZ V $(130.0-41.0 \mathrm{~cm}$ depth) starts with a $16 \mathrm{~cm}$ thick interval of dark grey millimetre-scale laminated calcareous sediments, followed by brown millimetreto-centimetre-scale laminated sediments until $41.0 \mathrm{~cm}$ depth. Laminations are only poorly preserved between 63.0 and $41.0 \mathrm{~cm}$ depth. The uppermost sediments of LZ VI $(41.0$ $0.0 \mathrm{~cm}$ depth) consist of homogenous brownish-greyish calcareous sediments, which are rich in aquatic plant remains. The uppermost centimetre is enriched in calcite and exhibits greyish faint laminations. 


\subsection{Sediment micro-facies analysis}

Microscopic sediment analysis revealed that clastic sublayers are present throughout the finely laminated sediments below $63.0 \mathrm{~cm}$ depth (Fig. 4a). These clastic sublayers are variably intercalated with calcitic, aragonitic, and organic sublayers and thus form different types of cyclic successions. In total, we classified six different types of sublayer successions as described below. The name for these types reflects the dominant sublayer for each of the six types. For example, the clastic-organic type is characterized by the dominance of clastic sublayers, while in the organic-clastic type organic sublayers dominate. The names are not related to the order of sublayer succession within each type. The changing dominance of different sublayer successions reflects the lithozones.

\subsubsection{Clastic-aragonitic type}

Clastic-aragonitic laminae are rare $(2.7 \%)$, mainly occurring in LZ I and particularly at $600.0-605.0$ and $609.0-616.0 \mathrm{~cm}$ composite depths. This subtype is composed of three sublayers, and the mean thickness is $0.59 \mathrm{~mm}$ (Figs. 4a (A), S2a). These laminae exhibit the general pattern of clastic-organic laminae in LZ I, with a coarse-grained and thick basal detrital sublayer, but the overlying mixed (detrital calcite, mica, fsp (feldspar), qtz (quartz), and medium amounts of endogenic calcite) fine-grained sublayer additionally contains idiomorphic aragonite needles that are not found in clastic-organic varves. The sublayer succession ends with an amorphous organic matter sublayer.

\subsubsection{Calcitic-clastic type}

The deposition of calcitic-clastic laminae $(6 \%)$ with a dominating endogenic calcite sublayer is restricted to LZ II. This subtype is composed of three sublayers and the mean thickness is $0.41 \mathrm{~mm}$, with a maximum of $2.0 \mathrm{~mm}$. Calcitic-clastic laminae (Figs. 4a (B) lower part, S2b) are usually characterized by a basal detrital sublayer, which, however, is not developed in all calcitic-clastic laminae. The overlying sublayer generally exhibits low species abundances of diatom frustules, chrysophyte cysts, aquatic plant remains, daphnia, ostracods, and characeae but massive and fine-grained endogenic calcite, which is not the case in the clastic-calcitic laminae subtype. Endogenic calcite formed in the water column (Fig. 4b (A)) is recognized by its well-developed idiomorphic rhombohedral shapes. Scattered detrital grains occasionally occur within the endogenic calcite matrix. One depositional cycle ends with an amorphous organic matter sublayer.

\subsubsection{Clastic-diatom type}

Clastic-diatom laminae (20\%) occur in LZ II, LZ III, and LZ IV. This subtype is composed of three sublayers and the mean thicknesses vary from $0.28 \mathrm{~mm}$ (LZ II) via $0.34 \mathrm{~mm}$
(LZ III) to $0.35 \mathrm{~mm}$ (LZ IV). The depositional cycle starts with a basal detrital sublayer, which is overlain by a finergrained mixed sublayer (detrital calcite, mica, fsp, qtz) occasionally containing chrysophytes and different diatom taxa. The third sublayer is formed by diatom blooms exclusively consisting of the planktic diatom species Cyclotella choctawhatcheeana (Anja Schwarz, TU Braunschweig, personal communication, 2019) (Figs. 4a (B) upper part, S2c).

\subsubsection{Clastic-calcitic type}

The second most common lamina subtype (23.5\%) is clasticcalcitic laminae (Figs. 4a (C) lower part, S2d), which are most abundant in LZ I, LZ II, LZ III, and LZ V. This subtype is composed of four to five sublayers, and the mean total thicknesses are $0.95 \mathrm{~mm}$ (LZ I), $0.35 \mathrm{~mm}$ (LZ II), $0.72 \mathrm{~mm}$ (LZ III), $1.56 \mathrm{~mm}$ (LZ IV), and the maximum value of $5.0 \mathrm{~mm}$ in LZ V. Clastic-calcitic laminae exhibit a basal detrital sublayer with a sharp lower boundary, which is followed by a bloom layer of chrysophytes and/or diatoms, occurring sporadically after and/or within the detrital sublayer. The third overlying mixed sublayer contains medium amounts of endogenic as well as fine-grained detrital calcite (Fig. 4c (A)), as well as mica, fsp, and qtz grains, but low amounts of diatom frustules and chrysophyte cysts. One depositional cycle typically ends with an amorphous organic matter sublayer. In LZ V, these clastic-calcitic laminae occasionally contain a very fine-grained, light greyish, micritic sublayer before the cycle ends with the amorphous organic sublayer.

\subsubsection{Organic-clastic type}

Horizons of organic-clastic laminae (5.2\%) with dominating organic sublayers are mainly present within LZ IV and LZ V (Figs. 4a (D), 2e), particularly at 261.0-252.0, 176.0-173.0, $150.0-126.0$, and $122.0-110.0 \mathrm{~cm}$ depths. This subtype is composed of three sublayers and the mean thicknesses being $0.49 \mathrm{~mm}$ (LZ IV) and $1.64 \mathrm{~mm}$ (LZ V) with a maximum of $9 \mathrm{~mm}$ in LZ V. Organic-clastic laminae exhibit an often horizontally discontinuous basal detrital sublayer (lens-shaped) in LZ IV, which is overlain by a mixed sublayer that contains detrital calcite, mica, fsp, and qtz grains, and many aquatic plant remains and periphytic diatoms (Achnanthes brevipes, Anja Schwarz, TU Braunschweig, personal communication, 2019), whose colony chains are often preserved. One deposition cycle ends with a yellowish amorphous organic matter layer.

\subsubsection{Clastic-organic type}

Clastic-organic laminae are present in all lithozones and most abundant in the record ( $42.5 \%$ of all observed and measured laminae). This micro-facies type is composed of four sublayers of which the most prominent is a basal clastic-detrital 
(a)

Varve deposition models

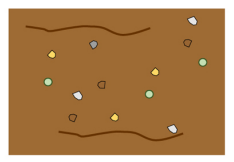

Homogenous sediments

with faint laminae in the upper 1.5 $\mathrm{cm}$ depth (grey bar)

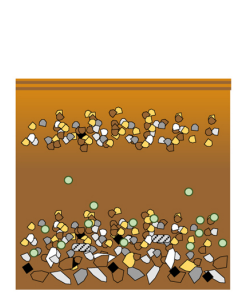

$\underline{\text { Clastic-organic laminations }}$

Winter amorphous organic layer Summer runoff event (clastic varves in $\mathbf{L Z ~ V}$ )

Summer mixed layer containin fine detrital grains and endogenic calcite

Spring coarse detrital runoff layer often with pennate diatoms an chrysophytes

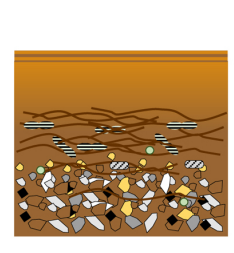

Organic-clastic laminations Winter amorphous organic layer Summer mixed layer containing detrital grains, rich in aquatic plant remains \& periphytic diator Achnanthes brevipes, daphnia,

Spring coarse detrital runoff laye often with pennate diatoms an

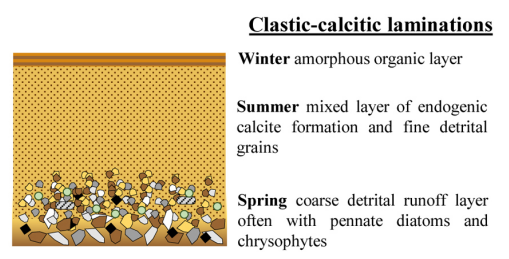

Clastic-diatom laminations

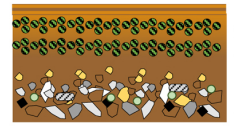

Winter amorphous organic layer Summer/Autumn Cyclotella choctawhatcheeana bloo Summer mixed layer Spring coarse detrital runoff laye often with pennate diatoms an chrysophytes

Calcitic-clastic laminations

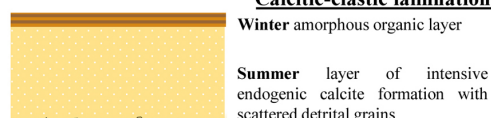

$.28=00908$
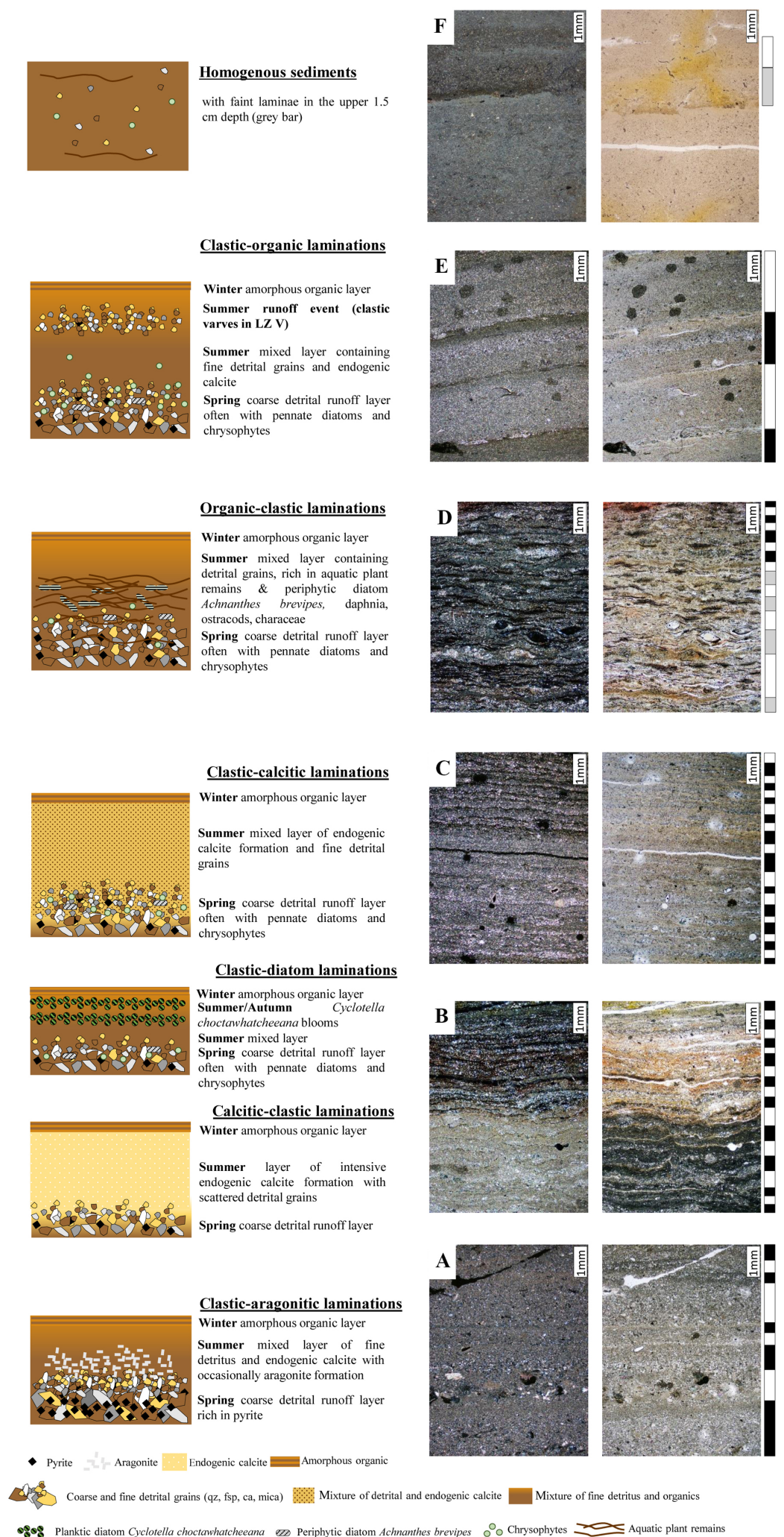

-

$\circ \circ$ Chrysophytes $\approx$ Aquatic plant remain

Figure 4. 


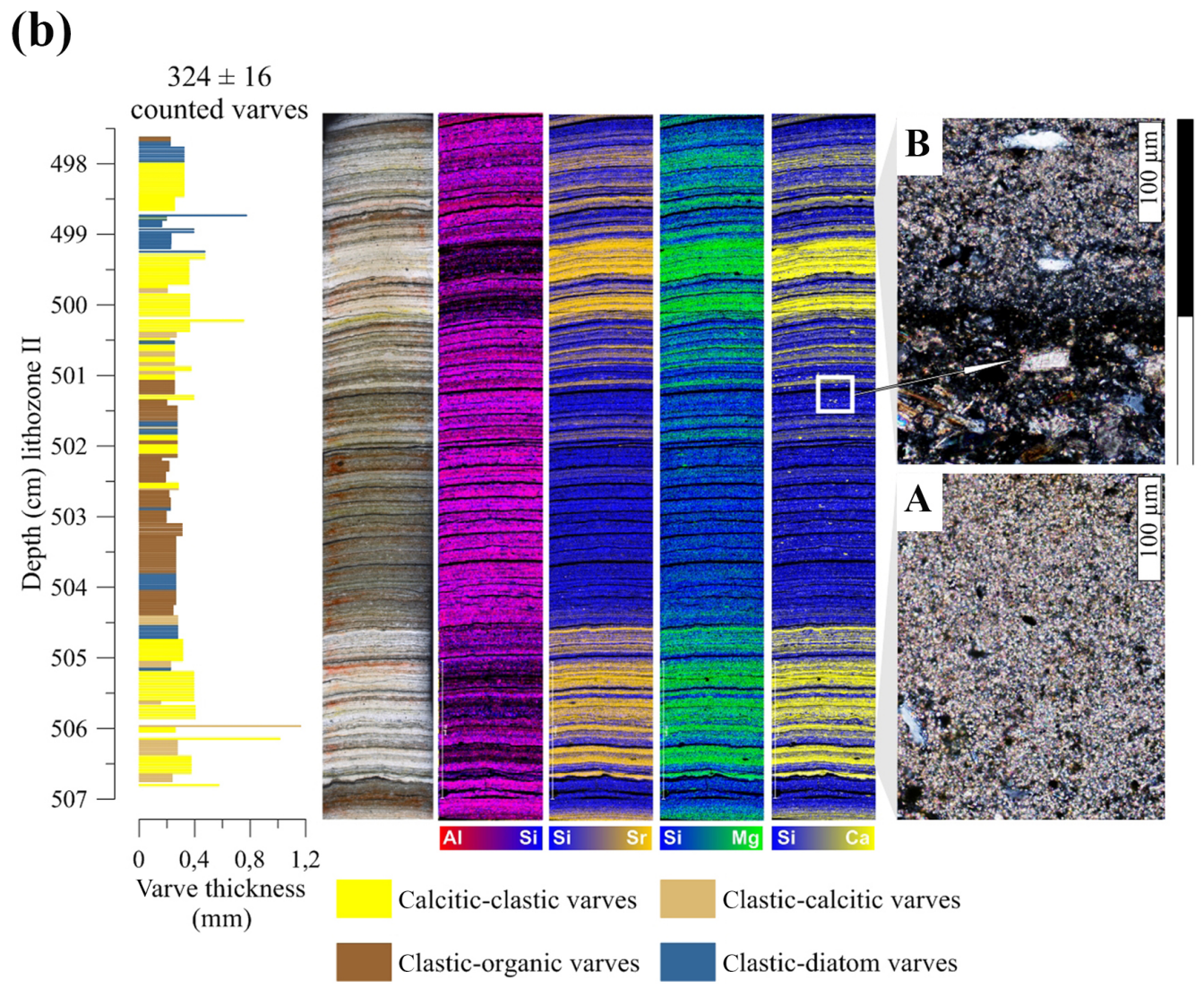

Figure 4.

sublayer with a sharp lower boundary. The basal detrital sublayer contains mainly detrital calcite which is distinguished from endogenic calcite by microscopic analyses. Detrital calcite is characterized by irregularly shaped grains and generally larger grain sizes of average of $0.6 \mathrm{~mm}$ and up to $1.82 \mathrm{~mm}$ in LZ I. Detrital layers further contain siliciclastic minerals such as mica, quartz (qtz) and feldspars (fsp). This basal layer is often, but not regularly, overlain by chrysophyte and/or diatom blooms and a third mixed sublayer containing mainly fine-grained detrital calcite, mica, fsp, and qtz with small amounts of endogenic calcite and varying amounts of diatom frustules, chrysophytes, characeae, ostracods, and daphnia. The deposition cycle ends with a yellowish layer of amorphous organic material.

The mean thickness of clastic-organic laminae differs between the lithozones. In LZ I, the mean thickness is $0.59 \mathrm{~mm}$ with a maximum thickness of $3.1 \mathrm{~mm}$. In LZ I, the basal detrital sublayer is thick and coarse grained; rich in pyrite; and contains mainly silty-to-fine sand-sized grains and occasionally sand-sized qtz, calcite, and fsp grains, whereas diatoms and chrysophytes are rare. In LZ II and LZ III, clastic-organic laminae are less thick with mean thicknesses of 0.27 and $0.48 \mathrm{~mm}$, respectively. In these lithozones, the basal sublayer contains no sand-sized particles. In LZ IV, mean varve thickness is $0.43 \mathrm{~mm}$ and the basal sublayer is often lens-shaped and horizontally discontinuous. In LZ V, between 130.0 and $63.0 \mathrm{~cm}$ depth, thickest clastic-organic laminae occur with a mean thickness of $1.5 \mathrm{~mm}$ and a maximum thickness of up to $7.0 \mathrm{~mm}$ (Figs. 4a (E), S2f). These clastic-organic laminae often include an additional detrital sublayer intercalated in the finer-grained mixed sublayer.

\subsubsection{Homogenous sediments}

The uppermost $41.0 \mathrm{~cm}$ of the sediment record consists of homogenous sediments, containing a fine-grained mix of autochthonous and allochthonous calcite, mica, qtz, and fsp. The sediments are generally rich in organic remains, such as aquatic plant remains, chrysophytes, diatoms, and chlorophytes (Botryococcus). Faint and discontinuous calcite laminae occur in the uppermost centimetre (Fig. $4 \mathrm{a}(\mathrm{F})$ ).

\subsection{XRF element mapping}

The two selected impregnated sediment blocks from 507 to $497.5 \mathrm{~cm}$ (XRF map 1 Fig. $4 \mathrm{~b}$ ) and from 346.5 to $338.5 \mathrm{~cm}$ depths (XRF map 2 Fig. 4c) contain calcitic-clastic, clastic-diatom, clastic-calcitic, and clastic-organic microfacies types. These sediments are dominated by alternating calcitic and siliciclastic sediments represented by the ele- 
(c)

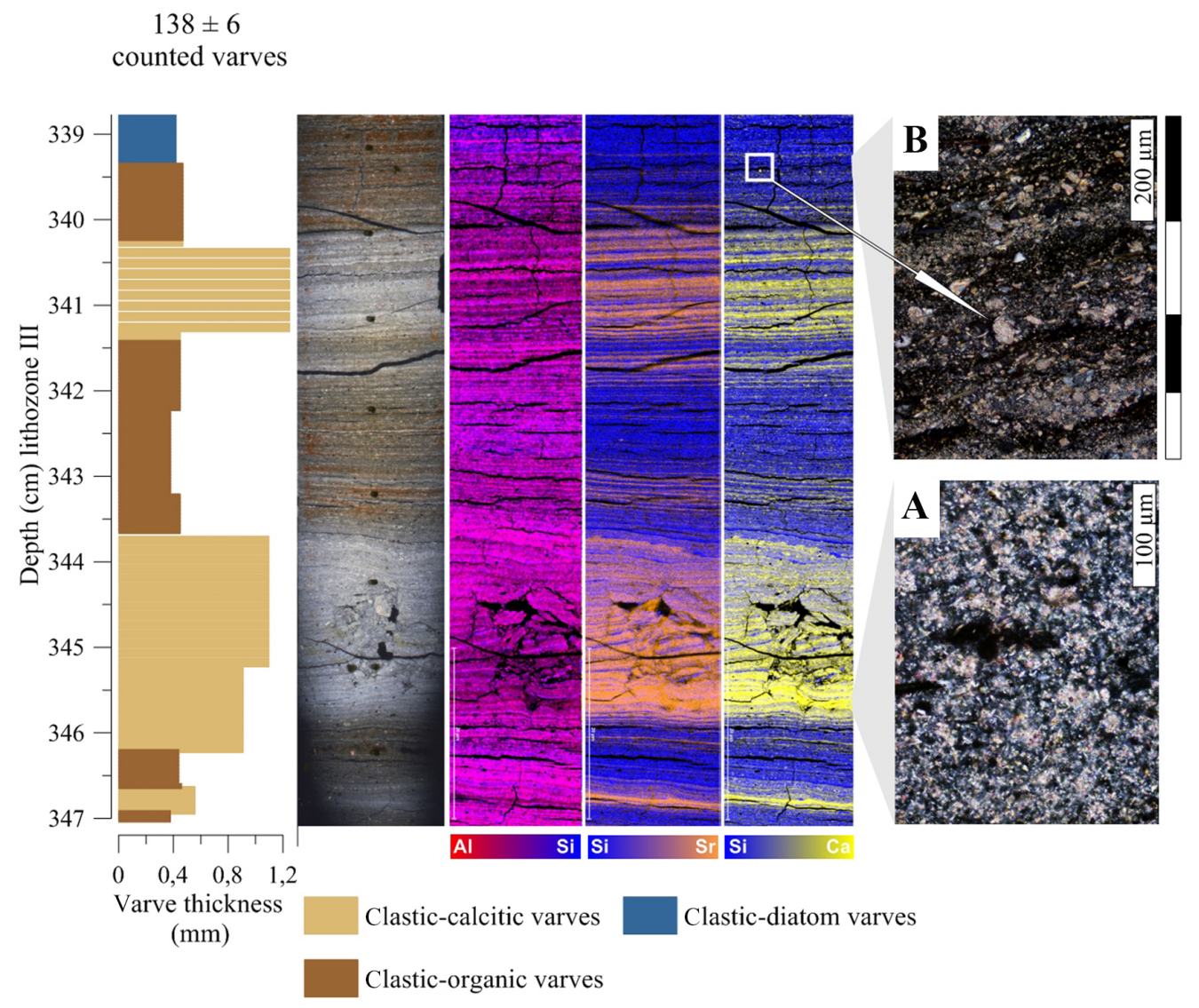

Figure 4. (a) Thin section pictures of different lamination (varve) types in cross-polarized (left) and plane polarized (right) light of the different lithozones LZ I to LZ V. (A) Clastic-organic laminations; (B) intercalation of clastic-organic, clastic-diatom and calcitic-clastic laminations; (C) intercalation of clastic-calcitic, clastic-organic, and clastic-diatom laminations (upper part); (D) organic-clastic laminations; (E) clastic-organic laminations; (F) homogenous sediments. Black/white/grey bars alongside the thin section pictures indicate one individual varve, but the reliability of grey bars (varves) is generally lower due to large amounts of aquatic plant remains and low preservation. Processrelated deposition models of the observed lamination/varve types illustrate the seasonal depositional successions (A-E). (b) XRF map 1: varve types and XRF element mapping of a thin section from LZ II from 507 to $497.5 \mathrm{~cm}$ depth. Element maps show an alternation of siliciclastic sediments with large amounts of $\mathrm{Si}$ and $\mathrm{Al}$ with calcite layers (Ca) with large amounts of $\mathrm{Sr}$ and $\mathrm{Mg}$ according to the presence of clastic-organic, clastic-diatom, clastic-calcitic, and calcitic-clastic varves, respectively. Micro-facies analyses show endogenic calcite within calcitic-clastic varves within the summer sublayer (image A). Clastic-organic and clastic-diatom varves are indicated by large amounts of Si and $\mathrm{Al}$ with only individual calcite (arrow image $\mathbf{B}$ ) and $\mathrm{Mg}$-calcite grains. Note that coinciding occurrences of individual elements result in colour mixing; for example, $\mathrm{Al}$ (red) and $\mathrm{Si}$ (blue) become pink. Endmembers of the Al-Si map are indicative for the presence of Al-rich clays and diatomaceous Si. (c) XRF map 2: varve types and XRF element mapping of a thin section from LZ III from 357 to $338.5 \mathrm{~cm}$ depth. Element maps show an alternation of siliciclastic sediments with large amounts of Si and Al with calcitic layers (Ca) with large amounts of $\mathrm{Sr}$ according to the presence of clastic-organic, clastic-diatom, and clastic-calcitic varves, respectively. Micro-facies analyses show mixed calcitic (resuspended and endogenic) summer sublayers within clastic-calcitic varves (image $\mathbf{A}$ ). Clastic-organic and clastic-diatom varves are indicated by large amounts of $\mathrm{Si}$ and $\mathrm{Al}$ with only individual calcite grains (arrow, image $\mathbf{B}$ ). Note that coinciding occurrences of individual elements result in colour mixing; for example, $\mathrm{Al}$ (red) and $\mathrm{Si}$ (blue) become pink. Endmembers of the Al-Si map are indicative for the presence of Al-rich clays and diatomaceous Si (blue).

ments $\mathrm{Ca}, \mathrm{Sr}, \mathrm{Mg}, \mathrm{Si}$, and $\mathrm{Al}$, respectively (Fig. $4 \mathrm{~b}$ and c). Colour variations of the element maps show that the calcitic and siliciclastic sediments are clearly separated in the XRF map 1 sample (Fig. 4b) but slightly more mixed in the XRF map 2 (Fig. 4c). In both XRF maps 1 and 2, the carbonate sublayers are enriched in $\mathrm{Sr}$ (Fig. $4 \mathrm{~b}$ and c), whereas in the XRF map 1 the additional enrichment of Mg (Fig. 4b) indicates the presence of Sr- and Mg-rich carbonates. Microfacies analysis shows that $\mathrm{Mg}$ - and $\mathrm{Sr}$-rich calcite sublayers in XRF map 1 are predominantly of endogenic origin (Fig. 4b 
(A)), whereas the Sr-rich calcite layers in XRF map 2 contain mixed endogenic and resuspended calcites (Fig. 4c (A)). Moreover, detrital carbonates occur predominantly as individual grains in the siliciclastic sediments and sublayers and are shown by $\mathrm{Ca}$ and $\mathrm{Mg}$ in the XRF element maps (Fig. 4b (B) and 4c (B)). Siliciclastic muds of clastic-organic and clastic-diatom varves are represented by the co-occurrence of $\mathrm{Al}$ and $\mathrm{Si}$ in the XRF element maps, whereas $\mathrm{Al}$ is absent in diatomaceous sublayers (Fig. $4 \mathrm{~b}$ and c).

\subsection{Chronology}

\subsubsection{Floating varve chronology $(623.5-63.0 \mathrm{~cm})$}

A floating varve chronology labelled as Chatvd19 (Fig. 5b) was established for the composite profile below $63.0 \mathrm{~cm}$ depth and comprises a total of 11259 counted and interpolated varves. Based on the interpretation of laminations as varves, 9026 of the total 11259 varves were counted, which is equal to $80.2 \%$. The first varve count reveals 9026 varves and is the base for the floating varve chronology. Although the total varve number of 8955 obtained by the second count is very similar to the first count, larger deviations between the two varve counts in individual sediment sections occur throughout the sediment record due to varying stages of varve preservation as expressed in the VQI (Fig. 5a). The largest deviations occur in LZ I $(603.0-595.0 \mathrm{~cm})$ with $23.7 \%$, in LZ II $(490.0-484.0 \mathrm{~cm})$ with $\sim 13 \%$, in LZ III $(413.0-405.0 \mathrm{~cm})$ with $\sim 16 \%$, in LZ IV $(141.0-134.0 \mathrm{~cm}$ depth) with $19.5 \%$, and in LZ V $(65.0-63.0 \mathrm{~cm}$ depth) with $7.7 \%$. The lowest deviations $(<1 \%)$ were obtained in $\mathrm{LZ}$ II at 539.0-530.0 and $498.0-490.0 \mathrm{~cm}$; in LZ III at 451.0 445.0, 421.0-413.0, 375.0-369.0, 299.0-290.0, and 282.0$275.0 \mathrm{~cm}$; in LZ IV at $197.0-190.0 \mathrm{~cm}$; and in LZ V at $125.0-$ $119.0,116.0-113.0$, and $73.0-65.0 \mathrm{~cm}$ depth. Interpolated sequences are unevenly distributed within the record and are mainly present within LZ IV. The longest interpolated sequences occur in LZ IV with $\sim 5 \mathrm{~cm}$ from $198.0-193.0 \mathrm{~cm}$ depth and in LZ III with almost $7 \mathrm{~cm}$ between 444.0 and $437.0 \mathrm{~cm}$ depth. A VQI (Fig. 5a) of 1 is represented by $5.6 \%$ of the total varves, VQI of 2 by $8.4 \%$, VQI of 3 by $26.4 \%$, VQI of 4 by $18.3 \%$, and VQI of 5 by $21.4 \%$. The calculated mean deviation between the two varve counts of $\sim 5 \%$ (Fig. 5a) is used as a conservative uncertainty for the floating varve chronology to consider high uncertainties in individual sediment sections in a more realistic way, despite the similar total number of varves counted. The floating varve chronology has a basal age of $11619 \pm 603 \mathrm{BP}$.

\subsubsection{Chronology of the non-varved uppermost sediments}

The uppermost $63.0 \mathrm{~cm}$ of the sediment profile are not varved and thus require alternative dating approaches including ${ }^{210} \mathrm{~Pb}$ dating, activity profiles of ${ }^{137} \mathrm{Cs}$, and sedimentationrate-based interpolation. First, we measured ${ }^{210} \mathrm{~Pb}$ activity concentrations of the uppermost $15 \mathrm{~cm}$ of short core SC17_7 and applied the CIC and CRS models (Figs. $5 \mathrm{c}$ and 6, Supplement Table S3). SC17_7 is correlated to the composite profile through macroscopically visible facies change at $1.0 \mathrm{~cm}$ composite depth and through a laminated section from 45.0 to $41.0 \mathrm{~cm}$ composite depth (Supplement Fig. S1). The CIC and CRS model-based chronologies are broadly consistent and particularly date sediments at $8.75 \mathrm{~cm}$ (SC17_7) or $7.5 \mathrm{~cm}$ composite depth to 1945/1946 CE (Figs. 5c and 6b, Supplement Table S3). This coincides with the onset of increased ${ }^{137} \mathrm{Cs}$ activity concentrations (Figs. 5c, 6c), marking the onset of nuclear weapon testing in 1945 CE (Bergkvist and Ferm, 2000; Kudo et al., 1998; Norris and Arkin, 1998). Therefore, we applied the date of $1945 \mathrm{CE}(8.75 \mathrm{~cm}$ in core SC17_7) as an anchor point for the chronology of the uppermost $63.0 \mathrm{~cm}$ of the composite profile. According to microfacies-based sedimentological correlation, this anchor point is located at $7.5 \mathrm{~cm}$ composite depth. The section of homogeneous sediments from this point down to $63.0 \mathrm{~cm}$ depth was interpolated. This interpolation is based on sedimentation rate calculations obtained by lead-210 dating and varve thickness measurements in adjacent sediment intervals. Calculations include sedimentation rates from the upper $7.5 \mathrm{~cm}\left(1.12 \mathrm{~mm} \mathrm{yr}^{-1}\right)$, from 15 varves $\left(1.9 \mathrm{~mm} \mathrm{yr}^{-1}\right)$ between 41.0 and $63.0 \mathrm{~cm}$ depth, and from 100 varves $\left(1.66 \mathrm{~mm} \mathrm{yr}^{-1}\right)$ below $63.0 \mathrm{~cm}$ depth, and they result in a mean SR of $1.56 \mathrm{~mm} \mathrm{yr}^{-1}$, corresponding to 356 interpolated years. Adding the number of 356 interpolated years to the radiometric date of $1945 \mathrm{CE}$ results in an age of $1589 \mathrm{CE}$ $(360 \mathrm{BP})$ at $63.0 \mathrm{~cm}$ depth. We assume a conservative uncertainty of ca. $10 \%$ as a maximum error for our interpolation. The anchor point thus has an age of $360 \pm 40 \mathrm{BP}$. The uncertainty of this anchor point is added to the varve counting uncertainty.

\subsubsection{Radiocarbon dating}

In total, we dated 36 samples of bulk organic carbon, daphnia remains, aquatic plant remains, and Ruppia martima seeds. Only two samples were terrestrial plant remains (wood fragments) and sufficiently large to be used for AMS ${ }^{14} \mathrm{C}$ dating (Table 2, Figs. 5 and 7). Except the two ages from terrestrial plant remains (Poz-54302 with $9988 \pm 203 \mathrm{cal} \mathrm{BP}$ and Poz63307 with $6140 \pm 137 \mathrm{cal} \mathrm{BP}$ ), all other ages deviate from the varve chronology between 155 years at $0.0 \mathrm{~cm}$ depth and 6150 years at $585.0 \mathrm{~cm}$ depth (Fig. 7). We observe a general trend of decreasing deviations up core with the maximum deviation of $\sim 6150$ years at $585.0 \mathrm{~cm}$ depth in LZ I. Looking at more detail, the deviations between radiocarbon and varve ages exhibit a prominent stepwise increase particularly at the boundary between LZ IV and LZ V when it abruptly decreases from $\sim 3000$ to $\sim 1000$ years. Modern aquatic plants collected during the field campaign in 2012 showed large modern reservoir ages of $330 \pm 30$ and $2425 \pm 25{ }^{14} \mathrm{C}$ years, and living daphnia yielded ages of $225 \pm 30{ }^{14} \mathrm{C}$ years. 
$\begin{array}{ll}\text { (a) Uncertainty } & \text { (b) Age model }\end{array}$ estimates (c) Constraining the uppermost age-depth relationship

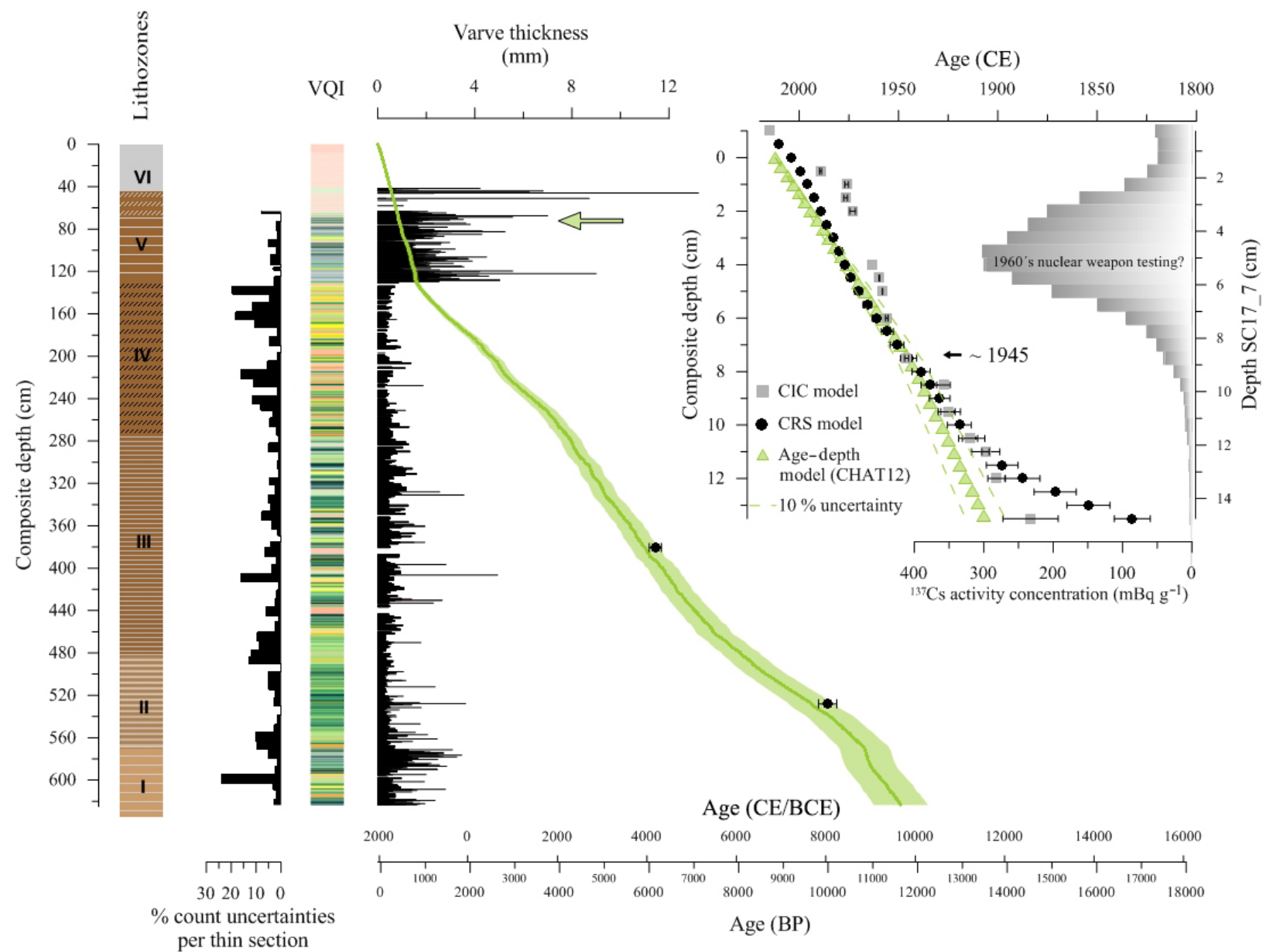

Cal. ${ }^{14} \mathrm{C}$ ages (IntCal13,Oxcal 4.3) : • Wood

Varve quality index

Varve chronology

\begin{tabular}{|lllllll}
\hline 0 & 1 & 2 & 3 & 4 & 5
\end{tabular}

- Varve thickness $\multimap$ Beginning of continuously varved sediments

Figure 5. (a) Varve counting uncertainty estimates (mean of $5 \%$ is green) and VQI distribution. (b) Age model of the floating varve chronology (Chatvd19) from 63.0 to $623.5 \mathrm{~cm}$ depth with a basal age of $11619 \pm 603 \mathrm{BP}$ (light green). The black line shows the measured varve thickness and black dots mark the distribution of calibrated AMS ${ }^{14} \mathrm{C}$ ages (with $95.4 \%$ probability range) of wood pieces (Table 2). (b) ${ }^{210} \mathrm{~Pb}$ CIC (grey squares) and CRS (black dots) age models; ${ }^{137} \mathrm{Cs}$ activity concentration profile and constrained age model for the uppermost part of the composite profile (green triangles).

\section{Discussion}

\subsection{Interpretation of fine laminations as varves}

The construction of varve chronologies relies on the proof of seasonal origin of fine laminations (Brauer et al., 2014; Ojala et al., 2012; Zolitschka et al., 2015). Laminations are absent in the upper $63.0 \mathrm{~cm}$ of the Chatyr Kol lake sediment core and cyclic successions of mixed clastic laminations are only observed below this depth. Therefore, the seasonal origin of the Chatyr Kol sediments cannot be proved through modern ob- servation in sediment traps, because no varves are formed in the present day. Instead, we applied process-related deposition models (Fig. 4a) based on detailed micro-facies analyses obtained from petrographic thin sections and compared our observations with varve types described in literature (Brauer, 2004; Zolitschka et al., 2015). We associate the observed successions of different types of mixed clastic laminations with the formation of different seasonal sublayers that are known from lakes with carbonaceous catchments (Brauer and Casanova, 2001; Kelts and Hsü, 1978; Lauterbach et al., 2011, 2019) and high-altitude glacial environments (Guyard 


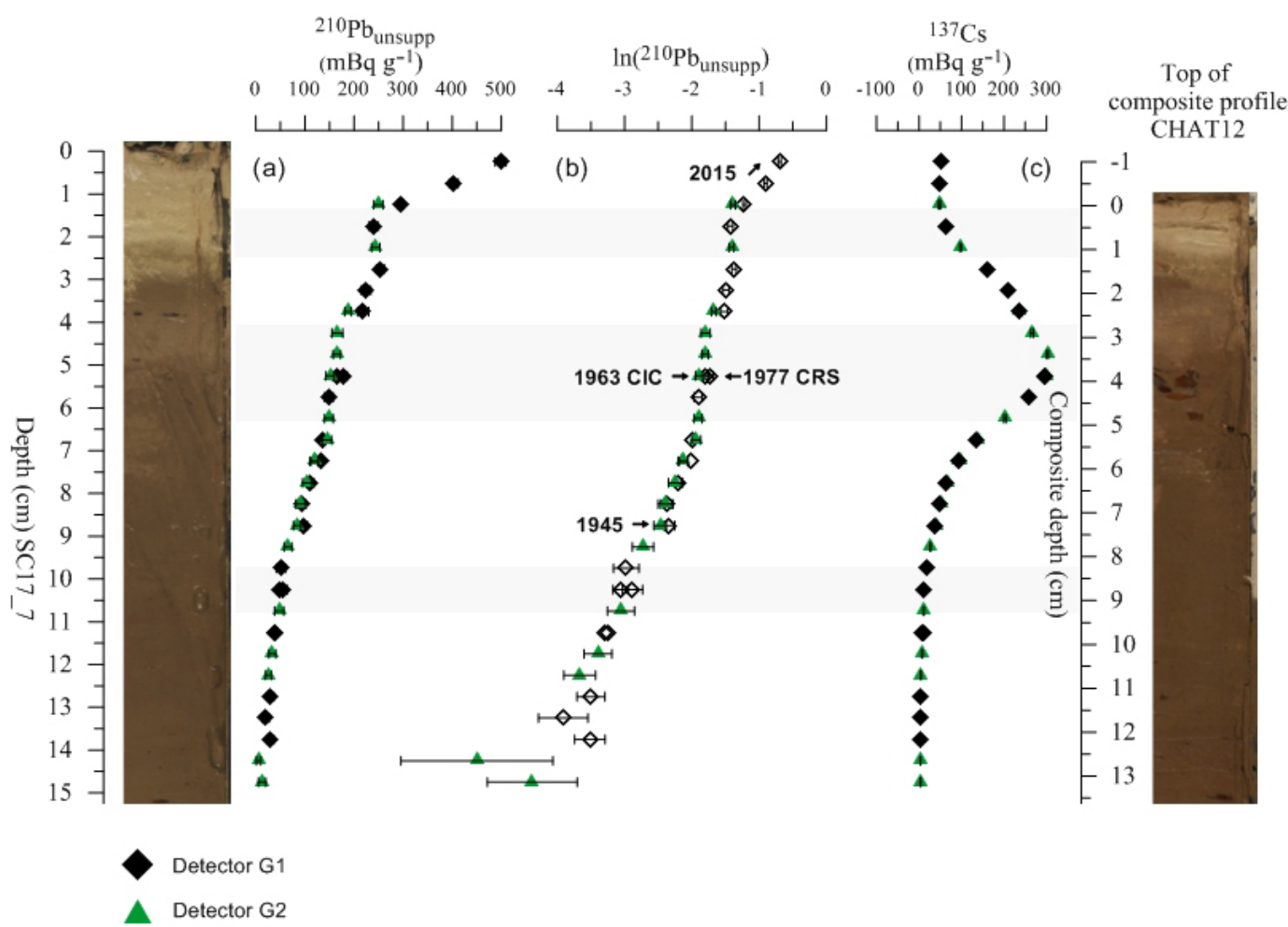

Figure 6. Gamma spectrometry results of the gravity core SC17_7. Light grey intervals indicate uncorrelated sequences of the $1 \mathrm{n}^{210} \mathrm{~Pb} \mathrm{unsupp}$ vs. depth profile which affected the CIC model calculations (Supplement Fig. S2, Supplement Tables S2, S3). Core pictures of the upper part of the composite profile CHAT12 (right) and the gravity core SC17_7 (left) illustrate the facies change to calcite-enriched sediments in the uppermost centimetre.

et al., 2007; Leemann and Niessen, 1994). The observed successions of sublayers are interpreted as mixed varve types (clastic, organic, and endogenic) as defined by Zolitschka et al. (2015).

Varve formation at Chatyr Kol lake is related to the high seasonality of the local climate with an ice cover during winter as well as strong annual variations of the temperature and precipitation affecting productivity, endogenic carbonate formation, and local runoff. Varve preservation is promoted by the unique morphology of the deep western lake basin, where anoxic bottom water conditions can be maintained even under relatively low lake levels (Fig. 2).

We interpret the annual sedimentary cycle to always start with the deposition of a basal detrital sublayer with a sharp lower boundary, which results from winter/spring snow and/or glacial melt (Guyard et al., 2007; Leemann and Niessen, 1994; Zolitschka et al., 2015) after the ice breakup around April (Shnitnikov et al., 1978). Runoff with suspended sediment load is then likely directed through the Kegagyr River in the east but may also be the result of surface runoff through the activation of several widely distributed smaller tributaries in the catchment (Fig. 1).

Basal detrital sublayers are generally overlain by blooms of chrysophytes and/or diatoms within clastic-organic, organic-clastic, clastic-diatom, and clastic-calcitic varve types. Chrysophytes and/or diatom blooms develop as a consequence of the available nutrients provided by runoff and spring overturn in combination with rising temperatures during the summer season (Zolitschka et al., 2015). The productive phase in calcitic-clastic varves is, however, reflected by calcite precipitation, which is the main carbonate phase (endogenic, detrital, and resuspended) in the Chatyr Kol sediments. The formation of endogenic calcite in Chatyr Kol lake is controlled by (1) photosynthesis, when high aquatic productivity lowers the concentrations of $\mathrm{CO}_{2}$, increases the $\mathrm{pH}$ of the lake water, and leads to a reduced solubility of $\mathrm{CO}_{3}^{2-}$ (Hodell et al., 1998; Kelts and Hsü, 1978; Zolitschka et al., 2015); (2) evaporation leading to an oversaturation of carbonate ions; and (3) sufficient supply of dissolved cations either through surface runoff or groundwater inflow (Shapley et al., 2005). Changes in weathering and hydrological conditions can lead to variations in the supply of $\mathrm{Ca}^{2+}$ and $\mathrm{Mg}^{2+}$ ions and subsequently change the $\mathrm{Mg} / \mathrm{Ca}$ ratio of the lake water (Müller et al., 1972). The formation of aragonite requires high lake water $\mathrm{Mg} / \mathrm{Ca}$ ratios $(>12)$, whereas magnesium-calcite forms at lower $\mathrm{Mg} / \mathrm{Ca}$ ratios (Kelts and Hsü, 1978; Müller et al., 1972). XRF element intensity maps do not provide quantitative results but do indicate that $\mathrm{Mg}$ 


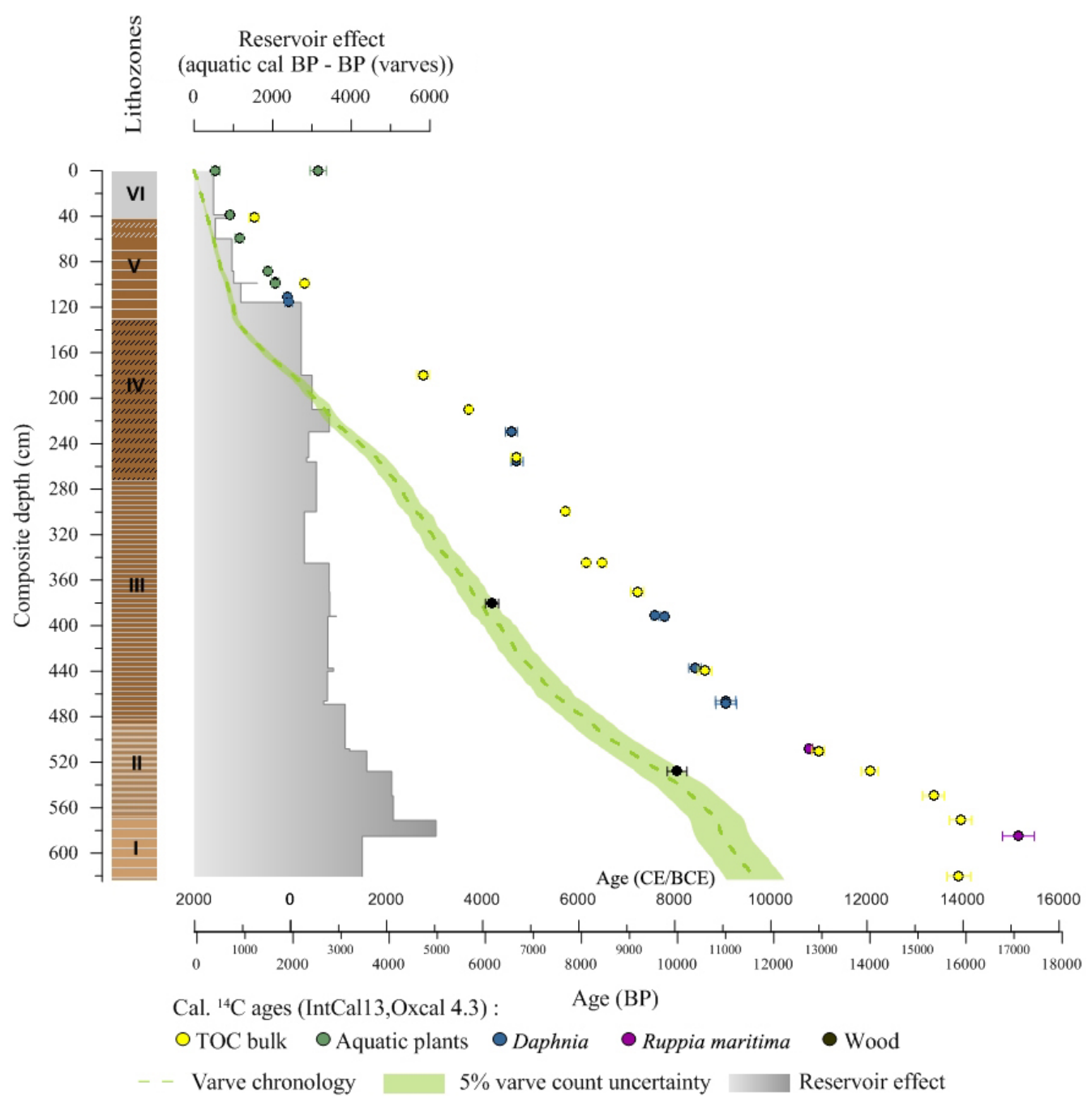

Figure 7. Radiocarbon reservoir effect (grey step plot). The reservoir effect was determined by the difference between aquatic (cal BP) (coloured symbols) and varve ages (green). Floating varve chronology (green) and distribution of calibrated AMS ${ }^{14} \mathrm{C}$ ages (with $95.4 \%$ probability range) of wood pieces, TOC bulk, aquatic plant remains, daphnia, and Ruppia maritima remains (Table 2).

is abundant in the XRF map 1 from LZ II, which results in the formation of endogenic Sr- and Mg-rich calcites (Fig. 4b (A)).

Aragonite precipitates, related to an evaporative concentration in summer, were only microscopically observed in the intervals between 600.0 and $605.0 \mathrm{~cm}$ and between 609.0 and $616.0 \mathrm{~cm}$ composite depth, suggesting that $\mathrm{Mg} / \mathrm{Ca}$ ratios probably remained above $\mathrm{Mg} / \mathrm{Ca}$ ratios $>12$.

After the spring-to-early-summer lake productivity, the deposition of a mixed sublayer consisting of silt- to clay-sized detrital grains and small-to-medium amounts of endogenic calcite is observed in all lamination types (Figs. 4a, S2). In clastic-calcitic varves, the mixed sublayers appear different and include especially resuspended calcite as evidenced also in $\mathrm{Ca}$ and $\mathrm{Sr}$ intensities (Figs. 4a (C), 4c (A), S2d). The mixed sublayer indicates resuspension of shore material (littoral calcite) to the core location due to, for example, wind- induced wave activity and weak runoff during the ice-coverfree season from around April to October (Shnitnikov et al., 1978).

The intercalation of discrete detrital layers within the mixed sublayer (Figs. 4a (E), S2e), as observed in clasticorganic laminae in $\mathrm{LZ} \mathrm{V}$, indicates pulses of runoff of suspended material which may be caused by late rainfall events in summer (Aizen et al., 2001; Shnitnikov et al., 1978).

One annual depositional cycle usually ends with the deposition of a thin sublayer of very fine amorphous organic matter which is deposited under quiet water conditions when the lake was ice covered (Fig. 4a). In lithozone V, an additional micritic sublayer is deposited before the amorphous organic sublayer at the end of the seasonal cycle in clastic-calcitic laminae when water turbulence is low. 


\subsection{Varve counting and chronology construction}

The interpretation of different types of fine laminations allowed for varve counting as a main tool for constructing the Chatyr Kol chronology largely based on incremental methods. Around $80 \%$ of the varves in the sediment record are double counted in petrographic thin sections, while the remaining part of ca $20 \%$ had to be interpolated based on sedimentation-rate estimates due to poor varve preservation. The resulting chronology comprises 11259 years and is anchored to the absolute timescale at $63.0 \mathrm{~cm}$ sediment depth supported by a combination of lead-210 dating and occasional sedimentation rate measurements as described below. The resulting age-depth model is within uncertainties in good agreement with two calibrated AMS ${ }^{14} \mathrm{C}$ dates of wood pieces at $380.5 \mathrm{~cm}$ depth $(6140 \pm 137 \mathrm{cal} \mathrm{BP}$; Poz-63307) and at $528.0 \mathrm{~cm}$ depth $(9988 \pm 203 \mathrm{cal} \mathrm{BP}$; Poz-54302) (Fig. 5b, Table 2). The corresponding varve-based ages are $5905 \pm$ 320 and $9611 \pm 505 \mathrm{BP}$, respectively. As for all chronologies, uncertainties are inherent also to varve chronologies, which are commonly assessed via replicate counts (Brauer and Casanova, 2001; Lamoureux, 2001; Lotter and Lemcke, 1999; Ojala et al., 2012; Żarczyński et al., 2018; Zolitschka et al., 2015). However, there is no standard procedure on how to calculate and present the uncertainties (Ojala et al., 2012; Zolitschka et al., 2015). Commonly, mean values of replicate count differences, the difference of maximum and minimum counts, or their standard deviation is reported (Brauer et al., 2014; Ojala et al., 2012; Żarczyński et al., 2018; Zolitschka et al., 2015). Despite the inevitable increase of cumulative uncertainties with age or depth, systematic uncertainties arise and are caused by changes in varve preservation, strongly and abruptly varying sedimentation rates, and the challenging differentiation of varve types with complex structures (Ojala et al., 2012; Żarczyński et al., 2018; Zolitschka et al., 2015). The overall very small difference between the two counts of the Chatyr Kol varved record of only -71 varves is due to the compensating effect between over- and underestimations of varve counts throughout the record. For the floating varve chronology, we therefore compare the results for each individual thin section comprising between a maximum of $324(506.8-497.6 \mathrm{~cm})$ and a minimum of 13 (varves) $(65.4-63.0 \mathrm{~cm})$ (Figs. 5a, 8).

Counting uncertainties for individual thin sections are reported as their percentage deviation from the first count used for the chronology and range between $0 \%$ and $23.7 \%$ (Figs. 5a, 8). Largest deviations of $23.7 \%$ in LZ I are caused by a low visibility of varve boundaries and by coring artefacts. Deviations of $\sim 13 \%$ in LZ II and of $\sim 16 \%$ in LZ III result from the abrupt intercalations between clasticorganic, clastic-diatom, clastic-calcitic, and calcitic-clastic varve types with varying varve thicknesses (Fig. 4b, c). Deviations in LZ IV with a maximum of $19.5 \%$ coincide with generally lowest VQI values (Fig. 8) and result from the domination of clastic-organic and organic-clastic varves with

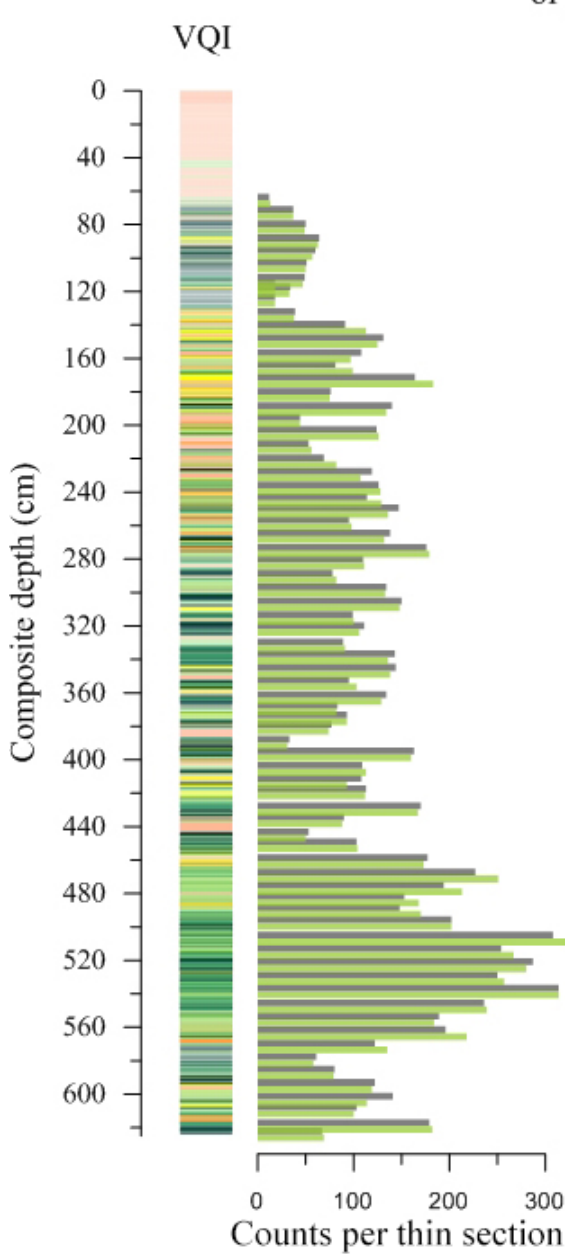

Percentage deviation of the two varve counts $\begin{array}{llllll}0 & 5 & 10 & 15 & 20 & 25\end{array}$

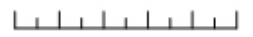

$$
\begin{aligned}
& \text { Varve quality index } \\
& \begin{array}{|lllllll}
\hline 0 & 1 & 2 & 3 & 4 & 5 \\
\hline
\end{array}
\end{aligned}
$$

Figure 8. VQI counting differences for individual thin sections (green represents first count, black represents second count, and their percentage deviation is given).

lowest thicknesses and discontinuous basal detrital sublayers (Fig. 4a (D)), leading to generally higher counting uncertainties. Lowest deviations of $<1 \%$ in LZ II, LZ III, LZ IV, and in LZ V represent best preservation and thus easily countable varves of different varve types. Generally, clastic-organic and clastic-calcitic varves with higher varve thickness, especially in LZ V, are most reliably countable. The relatively high uncertainties of $7.7 \%$ in LZ V are due to the low number of varves comprised in individual thin sections (Fig. 8). For the total uncertainty estimate for the floating varve chronology, we use the mean of $\pm 5 \%$ calculated from the uncertainties for each $10 \mathrm{~cm}$ interval. This conservative estimate is more realistic than the very low difference in the two repeated 
varve counts. An uncertainty of $5 \%$ is in the range of varve chronologies reported elsewhere (Ojala et al., 2012).

Since the uppermost $63.0 \mathrm{~cm}$ of the sediment profile is largely homogeneous, the varve chronology is floating and needs to be anchored to an absolute chronology at this point. The interpolation with a mean SR derived from the combination of the consistent CIC and CRS ${ }^{210} \mathrm{~Pb}$ marker (1945 CE), the SR derived from discontinuously varved sequences between 41.0 and $63.0 \mathrm{~cm}$ depth, and from 100 measured varves below $63.0 \mathrm{~cm}$ depth seems to be the best approach for constraining the uppermost age-depth relationship within the homogenous sediments, where further chronological markers are lacking. We are aware that the interpolation-based "floating" anchor point at $63.0 \mathrm{~cm}$ depth is prone to additional uncertainties. We considered this by assuming a higher uncertainty of $10 \%$ for this interval than that of $\pm 5 \%$ for the floating varve chronology.

\subsection{Radiocarbon reservoir effects}

Compared to the floating varve chronology, including two terrestrial (wood) AMS ${ }^{14} \mathrm{C}$ dates, we observed a general trend of decreasing reservoir effects of dated aquatic material up core with the maximum deviation of $\sim 6150$ years at $585.0 \mathrm{~cm}$ depth $(10930 \pm 570 \mathrm{BP})$ in LZ I (Fig. 7). The stepwise decrease of deviations between radiocarbon and varve ages is most pronounced at the boundary between LZ IV and LZ V, when it abruptly decreases from $\sim 3000$ to $\sim 1000$ years. The reservoir effect generally depends on the rate of atmospheric $\mathrm{CO}_{2}$ exchange between the water column and the air, internal mixing dynamics, and the input of ${ }^{14} \mathrm{C}$-depleted carbonaceous material (Ascough et al., 2010; Jull et al., 2013; Keaveney and Reimer, 2012; Lockot et al., 2016; MacDonald et al., 1991). The catchment of Chatyr Kol lake exhibits several sources that could be responsible for a ${ }^{14} \mathrm{C}$ depletion of dissolved carbon species in the lake water. Highest reservoir ages in the early Holocene are likely the result of the combined influence of these sources: (1) the input of old, ${ }^{14} \mathrm{C}$-depleted $\mathrm{CO}_{2}$ with glacial meltwater (cf. Hall and Henderson, 2001) at the onset of a warming Holocene and (2) the weathering and erosion of the northern outcropping limestones, which led to the release and input of dissolved bicarbonate to the lake (cf. Abbott and Stafford, 1996; Hutchinson et al., 2004). Both processes lead to a ${ }^{14} \mathrm{C}$ depleted $\mathrm{CO}_{2}$ and $\mathrm{HCO}_{3}^{-}$uptake during photosynthesis by, for example, submerged aquatic plants like Ruppia martima at $585.0 \mathrm{~cm}$ depth (Fig. 7) and by phytoplankton, on which daphnia feed and which therefore also show similar reservoir effects. A high detrital input and thus a potentially high input of dissolved bicarbonate is supported by increased varve thicknesses during the early Holocene (Sect. 5.4.1, Fig. 9). Furthermore, (3) thawing of permafrost since the beginning of a warming Holocene might have released dissolved ${ }^{14} \mathrm{C}$ depleted organic material and thus affect the ${ }^{14} \mathrm{C}$ TOC bulk measurements. Our field-trip observations and observations by Shnitnikov et al. (1978) of modern permafrost reduction and the development of thermokarst in the southern part of the catchment around the neighbouring Maloye lake (Fig. 1) support this assumption. The cause of a stepwise reservoir effect reduction is therefore likely also related to the combined effect of a generally decreasing glacial influence and a decreasing input of bicarbonate until $\sim 1150 \mathrm{CE}$ at the boundary between LZ IV and LZ V (Figs. 7, 9). The abrupt decrease of the reservoir effect after $\sim 1150 \mathrm{CE}$, despite an increase in detrital carbonate supply (Sect. 5.4.5, Fig. 9), might be related to the silting up of the basin, leading to a shallower water depth, which is more susceptible to water circulation and an enhanced atmospheric $\mathrm{CO}_{2}$ exchange (cf. Geyh et al., 1997).

\subsection{Holocene variations in varve micro-facies}

The Chatyr Kol lake sediment profile comprises six different varve types (Sect. 4.2, Figs. 4a, 2), whose occurrences showed varying dominance in the different lithozones that are described below. The individual lithozones always comprised more than one varve type (Fig. 9) with a maximum of five different varve types occurring in LZ III and II to three varve types in LZ V.

\subsubsection{Lithozone I (623.5-566.0 cm: $11619 \pm 603$ to $10730 \pm 560 \mathrm{BP})$}

Lithozone I is characterized by relatively large and varying varve thicknesses and by the presence of clastic-organic, clastic-calcitic, and clastic-aragonite varves (Fig. 9 LZ I). Clastic-organic varves constitute about $57 \%$ of the observed and counted varve types, clastic-calcitic $29 \%$, and clasticaragonitic $14 \%$. Generally, thick detrital coarse-grained spring sublayers, which were observed in all varve types in this LZ, are indicative for intense runoff by winter/spring snow meltwater and/or by glacial thawing during summer (Shnitnikov et al., 1978) caused by highest insolation (Berger and Loutre, 1991; Chen et al., 2008; Jin et al., 2011; Li and Morrill, 2010) at the onset of a warming early Holocene. Glaciers of the inner Tian Shan started to retreat between $\sim 12$ and 8 kyr BP (Bondarev, 1997; Shnitnikov et al., 1978) causing enhanced detrital input into the lake. The low species abundances of aquatic plants (Ruppia Maritima or Potamogeton sp.), daphnia, and characeae reflect a littoral community and indicate a low aquatic productivity and a relative low lake level during this time. Clastic-calcitic varves appear at the base of the composite profile and towards the end of LZ I, whereas clastic-aragonitic varves dominate in the period from $\sim 11500$ to $11000 \mathrm{BP}$. Most likely, idiomorphic aragonite formed due to a combination of Mg-rich water supply to the lake and strong evaporative conditions causing lake water $\mathrm{Mg} / \mathrm{Ca}$ ratios of $>12$ (Kelts and Hsü, 1978; Müller et al., 1972). 


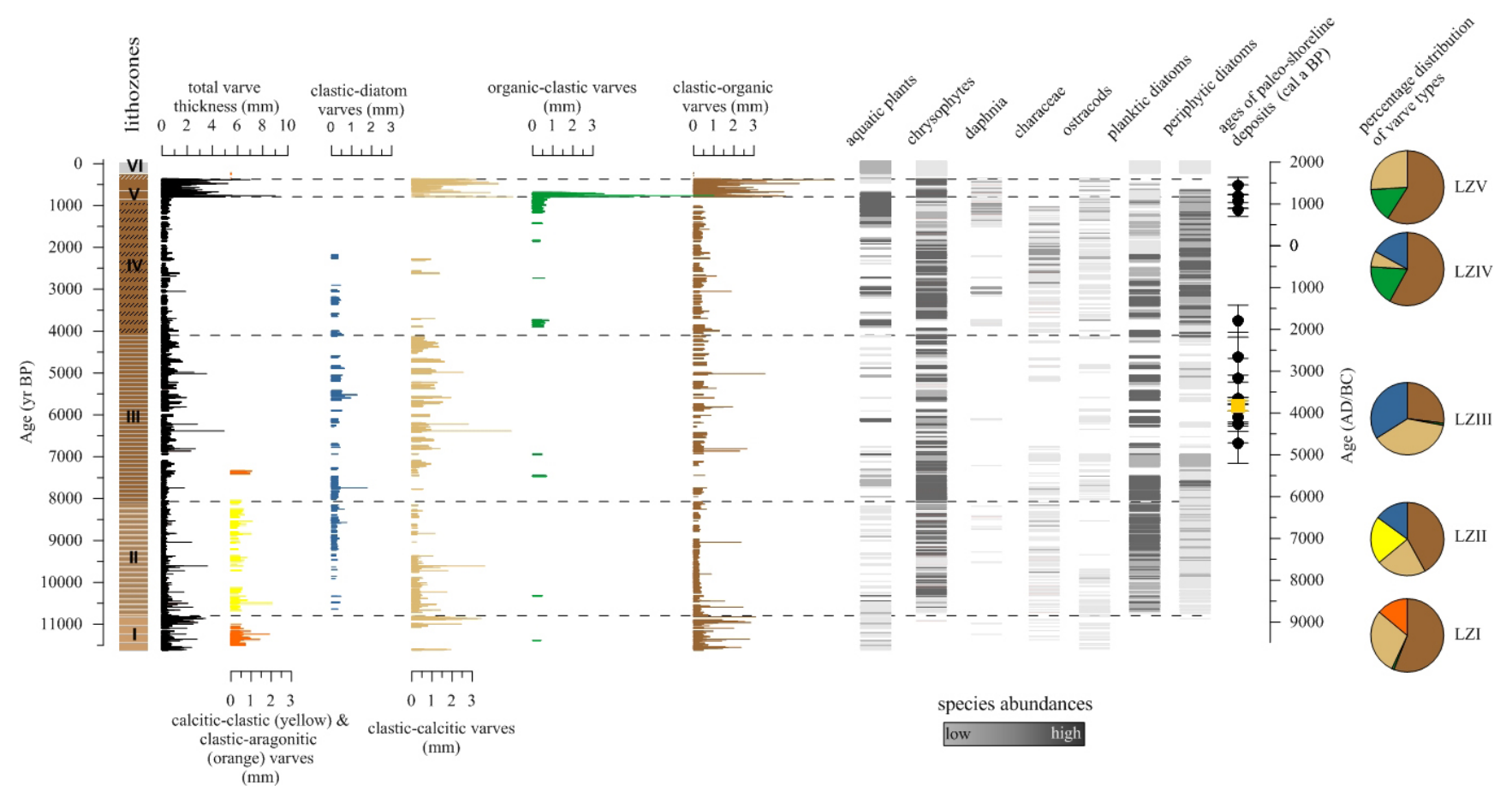

Figure 9. Holocene seasonal deposition patterns, semiquantitative species assemblages, and calibrated ${ }^{14} \mathrm{C}$ dates of palaeoshore deposits (black dots are from Shnitnikov et al. (1978), yellow square is from own sample taken in 2017) (Table 2). Percentage distribution of varve types in the different lithozones are shown.

\subsubsection{Lithozone II $(566.0-480.0 \mathrm{~cm}: 10730 \pm 560$ to $8040 \pm 430 \mathrm{BP})$}

In this lithozone calcitic-clastic varves constitute about $21 \%$ of the observed varves and clastic-calcitic varves $\sim 22 \%$, while clastic-organic varves make up $\sim 42 \%$ and clasticdiatom varves $\sim 15 \%$ (Fig. 9 LZ II). This lithozone is characterized by intercalations of calcitic varve types (calciticclastic and clastic-calcitic) with clastic-organic and clasticdiatom varves (Fig. 4b). The variations of these varve types might be related to external (climatic) forcing or lake-internal or sedimentation variability (Turner et al., 2016, and reference therein). XRF element maps show endogenic calcite sublayers that are enriched in $\mathrm{Sr}$ and $\mathrm{Mg}$, alternating with clastic ( $\mathrm{Si}$ and $\mathrm{Al}$ ) or diatom ( $\mathrm{Si}$ ) layers (Fig. 4b), suggesting Sr- and Mg-rich calcite in this lithozone, which indicates evaporative concentration (Müller et al., 1972). The shift of the dominant endogenic carbonate type from aragonite in LZ I to calcite in LZ II around $\sim 10730$ BP (Fig. 9 LZ II) coincides with an increase in biological and photosynthetic activity, as inferred from the establishment of a diverse lake fauna seen in high abundances of chrysophytes and planktic (Cyclotella choctawhatcheeana) and periphytic diatoms (Achnanthes brevipes), as well as of aquatic plants, ostracods, characeae, and few daphnia. Identifying the main drivers controlling endogenic carbonate formation thus remains speculative. Species assemblages and associated bio- logical activity during the summer season indicate favourable warm summers and sufficient nutrient supply through, for example, runoff. Because the species assemblages show mixed littoral and pelagic species abundances, these are interpreted as an indication for a low lake level.

\subsubsection{Lithozone III $(480.0-273.0 \mathrm{~cm}: 8040 \pm 350$ to $4140 \pm 230 \mathrm{BP})$}

The deposition of clastic-calcitic varves comprise $\sim 38 \%$ of the observed varves in this lithozone, while clastic-organic varves make up $\sim 27 \%$ and clastic-diatom varves $\sim 34 \%$ (Fig. 9 LZ III). Clastic-calcitic varves are generally thicker than the other varve types of this LZ, mainly because of exceptionally thick summer sublayers. These summer layers consist of endogenic calcite mixed with resuspended calcites and fine-grained detrital grains (Fig. 4a (C), 4c (A)). This is confirmed by elevated $\mathrm{Sr}$ values of the XRF element mapping, indicating the presence of $\mathrm{Sr}$-rich carbonates. These varves likely reflect increased resuspension of carbonates from the littoral zone due to wind-induced wave activity. As in LZ II, alternations of clastic-calcitic $(\mathrm{Ca}, \mathrm{Sr})$ (Fig. 4c (A)), clastic-diatom, and clastic-organic ( $\mathrm{Si}, \mathrm{Al}$ ) (Fig. 4c (B)) varves are characteristic for this lithozone as well. At $\sim 8040 \mathrm{BP}$ the deposition of calcitic-clastic varves ceased and is replaced by the deposition of clastic-calcitic, clastic-organic, and clastic-diatom varves probably due to 
decreasing summer insolation and lower summer temperatures (Berger and Loutre, 1991; Chen et al., 2008; Jin et al., 2011; Li and Morrill, 2010). In addition, higher lake levels since that time are indicated by the dominance of planktic diatoms and the occurrence of lake deposits at the eastern and southern shore, which have been dated from $6688 \pm 473$ to $4621 \pm 594 \mathrm{cal} \mathrm{BP}\left({ }^{14} \mathrm{C}\right.$ ages published by Shnitnikov et al. (1978) calibrated with OxCal4.3 and IntCal13). During our field work we found lake sediments on a shallow terrace $\sim 7 \mathrm{~m}$ above the current lake level east of the lake, which also revealed a mid-Holocene age of $5786 \pm 122 \mathrm{cal}$ BP (Poz109830 Table 2). Higher lake levels at that time have been explained by the preceding early Holocene glacier retreat in the catchment (Bondarev, 1997; Shnitnikov et al., 1978). However, more recently even minor glacial advances in the Aksai Basin east of the Chatyr Kol catchment ${ }^{10} \mathrm{Be}$ exposure dated between 7.5 and $\sim 4.5 \mathrm{ka}$ were reported (Koppes et al., 2008).

\subsubsection{Lithozone IV (273.0-130.0 cm: $4140 \pm 230$ to $800 \pm 60 \mathrm{BP}(1150 \pm 60 \mathrm{CE})$}

This lithozone contains clastic-organic (58\%), organicclastic $(18 \%)$, clastic-diatom $(17 \%)$, and clastic-calcitic varves $(6 \%)$ (Fig. 9 LZ IV). High abundances of planktic diatoms as well as clastic-diatom varves prevail until $2900 \mathrm{BP}$, whereas clastic-organic and organic-clastic varves with abundant aquatic plant remains and periphytic diatoms occur afterwards and dominate the sediments particularly after $\sim 2200$ BP. Abundant aquatic plant remains and periphytic diatoms can be explained by reworking due to wave activity and water column mixing during low lake levels. Low lake levels are inferred from the modern observation that aquatic plants occupy the shallow parts of the lake from $\sim 15.0$ to $0.5 \mathrm{~m}$. A decreased lake level combined with the shallow bathymetry of the lake basin (Fig. 1) further promotes large impacts on the species communities, which supports the changing abundances from a planktic to a littoral dominated fauna and flora after $\sim 2200$ BP. An increased mixing of the water body also caused a clear decline in varve preservation. The rate of detrital input as observed in clasticorganic, organic-clastic varves (Figs. 4a (D), 2e) is rather constant and mainly appears within the spring sublayer, suggesting stable snow melt runoff from $4140 \mathrm{BP}$ to $1150 \mathrm{CE}$. At $\sim 2600$ and at 2300 BP clastic-calcite varves with thickened summer sublayers appear for a few decades indicating enhanced resuspension.

\subsubsection{Lithozone $\mathrm{V}(130.0-41.0 \mathrm{~cm}: 1150 \pm 60 \mathrm{CE}$ to $1730 \pm 30 \mathrm{CE})$}

Clastic-organic varves constitute $59 \%$ of the observed varves in LZ V, clastic-calcitic varves $26 \%$ and organic-clastic

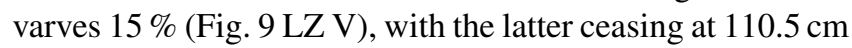
$(1260 \pm 50 \mathrm{CE})$. Varve micro-facies changes abruptly at
$130 \mathrm{~cm}$ depth or $1150 \mathrm{CE}$ from the dominance of organicclastic varves to dominating clastic-organic and clasticcalcitic varves. Within 5 years, varve thickness drastically increased from $\varnothing 0.43 \mathrm{~mm}$ in LZ IV to $\varnothing 1.52 \mathrm{~mm}$ in LZ $\mathrm{V}$ due to thicker summer sublayers. Thicker summer sublayers result from thicker mixed sublayers rich in algal remains (Botryococcus, chrysophytes, diatoms) and additional late summer detrital sublayers (Figs. 4a (E), S2f). Hence, the increase in summer layer thickness suggests both higher lacustrine productivity and an increase in summer runoff events. However, the reasons for these changes remain elusive and a relationship to known climatic periods like the Medieval Climate Anomaly and the Little Ice Age is not found. One might speculate that the frequent occurrence of late summer runoff layers either reflects convective rainfall events due to recycling of local moisture sources (Aizen et al., 2001) or changing atmospheric circulation regimes. Changes in boundary conditions in the catchment of the lake are unlikely since micro-facies analysis does not show pronounced changes in grain size distribution of the detrital material. $\mathrm{Hu}-$ man impact cannot fully be excluded but low indices of human and livestock fecal biomarkers (Schroeter et al., 2020) are an argument against major human impact. The presence of lake deposits at the northern and southern shores ca 1.5$1 \mathrm{~m}$ above present-day lake level dated at $1420 \pm 204 \mathrm{CE}$, $1044 \pm 160 \mathrm{CE}$, and $858 \pm 166 \mathrm{CE}$ (Shnitnikov et al., 1978) suggests that increased summer runoff events might have resulted in a more positive water budget and lake level rise.

\subsubsection{Lithozone VI $(41.0-0.0 \mathrm{~cm}: 1730 \pm 30 \mathrm{CE}$ to 2012 CE)}

At around $1730 \pm 30 \mathrm{CE}$ varve formation and/or preservation ceased and sediments became predominantly homogeneous. The cessation of varves might be related to enhanced mixing of the water column resulting in a loss of the oxygen minimum zone (Fig. 2a) caused by decreasing water depth due to silting, which accelerated with the abrupt increase in sedimentation rate at $1150 \mathrm{CE}$ and/or due to strengthening of the wind conditions and wave activity.

\section{Conclusions}

We present the first varved lake sediment record in arid Central Asia that covers almost the entire Holocene. The established floating varve chronology provides independent dating for a setting with scarce material for radiocarbon dating. In particular, our varve chronology allows for a quantification of changes in radiocarbon reservoir ages throughout the Holocene. The largest reservoir effect of $\sim 6150$ years in the early Holocene is likely caused by glacial melt and enhanced local erosion, resulting in a surplus of dead carbon. Lowest reservoir ages of $\sim 1000$ years and less in the late Holocene might be related to enhanced atmospheric $\mathrm{CO}_{2}$ exchange when the lake was shallower due to silting up of the 
lake basin and/or increased windiness, inducing increased water column mixing and $\mathrm{CO}_{2}$ exchange with the atmosphere. The construction of the varve-based chronology was only possible through detailed micro-facies analyses of the entire sediment sequence in overlapping thin sections that allowed for the development of seasonal deposition models for all observed types of fine laminations. Based on these models and their comparison with published varve micro-facies data, we interpret all six Chatyr Kol lamination types as varves. Compared to many other varved lake sediment records, the Chatyr Kol varves are very heterogeneous and a complex pattern of six different micro-facies types developed throughout the Holocene. All varve types are predominantly clastic and comprise variations of their summer sublayers with changing dominance of organic, diatom, calcitic, aragonitic, and additional detrital sublayers. Varve thickness changed accordingly with the varve micro-facies types, whereby the most conspicuous increase of varve thickness occurred at $1150 \mathrm{CE}$, which is caused by increased erosion and runoff. The increase in detrital input into the lake further caused an acceleration of the silting-up processes.

XRF element mapping results support our micro-facies analysis and provide additional information on the composition of carbonate sublayers and detrital carbonate. Microfacies analysis and XRF element mapping show major variations between partly $\mathrm{Mg}$ - and $\mathrm{Sr}$-rich sublayers in calciticclastic and clastic-calcitic varves with Al- and Si-rich sediments in clastic-organic and clastic diatom varves. Nevertheless, the complex succession and variations of varve types throughout the Holocene including major change points still requires further detailed investigations and interpretation together with other proxy data.

Data availability. The presented data are provided through PANGAEA: https://doi.org/10.1594/PANGAEA.909981 (Kalanke et al., 2019) and at https://varve.gfz-potsdam.de (last access: 11 June 2020).

Supplement. The supplement related to this article is available online at: https://doi.org/10.5194/gchron-2-133-2020-supplement.

Author contributions. JK performed the micro-facies analysis, ${ }^{210} \mathrm{~Pb}$ and ${ }^{137} \mathrm{Cs}$ gamma spectrometry, and wrote the article with contributions from all co-authors. JM designed the project and organized field work. SL carried out sediment coring and was responsible for ${ }^{14} \mathrm{C}$ dating. RU provided information about the catchment geology and lake level changes. RT carried out the XRF element mapping. AB supervised analyses and article writing.

Competing interests. The authors declare that they have no conflict of interest.
Acknowledgements. We are grateful for the suggestions of three anonymous reviewers and R. Staff, which helped to improve the article. We thank Sylvia Pinkerneil, Michael Köhler, Robert Schedel, and Denis Henning for retrieving the long piston cores from Chatyr Kol lake in 2012 in the framework of the project CADY (Central Asian Climate Dynamics, BMBF grant 03G0813). Sylvia Pinkerneil and Yvonne Beutlich are thanked for their help with the geochemical analyses. Sagynbek Orunbaev, Mirlan Daiyrov, Samat Kalmuratov, Gulzar Omurova, and Kalia Jusupova are acknowledged for their support during field trips. We further thank Dieter Berger, Gabriele Arnold, and Brian Brademann for thin section preparation as well as Georg Schettler ( $\dagger$ ) for his help with lead210 dating. This paper is a contribution to Topic 8 "Rapid Climate Change from Proxy data" within the climate initiative REKLIM of the Helmholtz Association.

Financial support. This research has been supported by the German Federal Ministry of Education (BMBF) through grant 03G0864B for the project CAHOL (Central Asian HOLocene), a subproject of the joint project CAME II (Central Asia Climate Tipping Points and their Consequences).

Review statement. This paper was edited by Richard Staff and reviewed by three anonymous referees.

\section{References}

Abbott, M. B. and Stafford, T. W.: Radiocarbon geochemistry of modern and ancient Arctic lake systems, Baffin Island, Canada, Quaternary Res., 45, 300-311, https://doi.org/10.1006/qres.1996.0031, 1996.

Academy of Science of the Kyrgyz SSR: Atlas of the Kyrgyz Soviet Socialistic Republic: Natural conditions and resources, State Agency of Cartography and Geodesy, Central Directorate for Geodesy and Cartography, Council of Minister of the USSR, Moscow, 1987.

Aizen, E. M, Aizen, V. B., Melack, J. M., Nakamura, T., and Ohta, T.: Precipitation and atmospheric circulation patterns at mid-latitudes of Asia, Int. J. Climatol., 21, 535-556, https://doi.org/10.1002/joc.626, 2001.

Aizen, V. B.: Association between atmospheric circulation patterns and firn-ice core records from the Inilchek glacierized area, central Tien Shan, Asia, Journal of Geophysical Research, 109, https://doi.org/10.1029/2003JD003894 https://doi.org/10.1029/2003JD003894, 2004.

Appleby, P.: Chronostratigraphic techniques in recent sediments, in: Tracking environmental change using lake sediments, Springer, https://doi.org/10.1007/0-306-47669-X_9, 2002.

Appleby, P. and Oldfield, F.: The calculation of lead-210 dates assuming a constant rate of supply of unsupported ${ }^{210} \mathrm{~Pb}$ to the sediment, Catena, 5, 1-8, https://doi.org/10.1016/S03418162(78)80002-2, 1978.

Ascough, P., Cook, G., Church, M., Dunbar, E., Einarsson, Á., McGovern, T., Dugmore, A., Perdikaris, S., Hastie, H., and Friðriksson, A.: Temporal and spatial variations in freshwater ${ }^{14} \mathrm{C}$ reservoir effects: Lake Mývatn, northern Iceland, Radiocarbon, 
52, 1098-1112, https://doi.org/10.1017/S003382220004618X, 2010.

Berger, A. and Loutre, M.-F.: Insolation values for the climate of the last 10 million years, Quaternary Sci. Rev., 10, 297-317, https://doi.org/10.1016/0277-3791(91)90033-Q, 1991.

Bergkvist, N.-O. and Ferm, R.: Nuclear Explosions 1945-1998, Stockholm: SIPRI, 2000.

Bondarev, L. G.: Fluctuations of local glaciers in the southern ranges of the former USSR: 18,000-8000 BP, Quatern. Int., 38, 103-108, https://doi.org/10.1016/S1040-6182(96)00023-7, 1997.

Boomer, I., Aladin, N., Plotnikov, I., and Whatley, R.: The palaeolimnology of the Aral Sea: a review, Quaternary Sci. Rev., 19, 1259-1278, https://doi.org/10.1016/S0277-3791(00)000020, 2000.

Brauer, A.: Annually Laminated Lake Sediments and Their Palaeoclimatic Relevance, in: The Climate in Historical Times: Towards a Synthesis of Holocene Proxy Data and Climate Models, edited by: Fischer, H., Kumke, T., Lohmann, G., Flöser, G., Miller, H., von Storch, H., and Negendank, J. F. W., Springer Berlin Heidelberg, Berlin, Heidelberg, https://doi.org/10.1007/978-3-66210313-5_7, 2004.

Brauer, A. and Casanova, J.: Chronology and depositional processes of the laminated sediment record from Lac d'Annecy, French Alps, J. Paleolimnol., 25, 163-177, https://doi.org/10.1023/A:1008136029735, 2001.

Brauer, A., Hajdas, I., Blockley, S. P. E., Bronk Ramsey, C., Christl, M., Ivy-Ochs, S., Moseley, G. E., Nowaczyk, N. N., Rasmussen, S. O., Roberts, H. M., Spötl, C., Staff, R. A., and Svensson, A.: The importance of independent chronology in integrating records of past climate change for the $60-8 \mathrm{ka}$ INTIMATE time interval, Quaternary Sci. Rev., 106, 47-66, https://doi.org/10.1016/j.quascirev.2014.07.006, 2014.

Chen, F., Yu, Z., Yang, M., Ito, E., Wang, S., Madsen, D. B., Huang, X., Zhao, Y., Sato, T., John B. Birks, H., Boomer, I., Chen, J., An, C., and Wünnemann, B.: Holocene moisture evolution in arid central Asia and its out-of-phase relationship with Asian monsoon history, Quaternary Sci. Rev., 27, 351-364, https://doi.org/10.1016/j.quascirev.2007.10.017, 2008.

De Grave, J., Glorie, S., Buslov, M. M., Izmer, A., Fournier-Carrie, A., Batalev, V. Y., Vanhaecke, F., Elburg, M., and Van den haute, P.: The thermo-tectonic history of the Song-Kul plateau, Kyrgyz Tien Shan: Constraints by apatite and titanite thermochronometry and zircon U/Pb dating, Gondwana Res., 20, 745-763, https://doi.org/10.1016/j.gr.2011.03.011, 2011.

Esper, J., Shiyatov, S. G., Mazepa, V. S., Wilson, R. J. S., Graybill, D. A., and Funkhouser, G.: Temperature-sensitive Tien Shan tree ring chronologies show multi-centennial growth trends, Clim. Dynam., 21, 699-706, https://doi.org/10.1007/s00382003-0356-y, 2003.

Fohlmeister, J., Plessen, B., Dudashvili, A. S., Tjallingii, R., Wolff, C., Gafurov, A., and Cheng, H.: Winter precipitation changes during the Medieval Climate Anomaly and the Little Ice Age in arid Central Asia, Quaternary Sci. Rev., 178, 24-36, https://doi.org/10.1016/j.quascirev.2017.10.026, 2017.

Geyh, M. A., Schotterer, U., and Grosjean, M.: Temporal changes of the ${ }^{14} \mathrm{C}$ reservoir effect in lakes, Radiocarbon, 40, 921-931, https://doi.org/10.1017/S0033822200018890, 1997.
Guyard, H., Chapron, E., St-Onge, G., Anselmetti, F. S., Arnaud, F., Magand, O., Francus, P., and Mélières, M.-A.: High-altitude varve records of abrupt environmental changes and mining activity over the last 4000 years in the Western French Alps (Lake Bramant, Grandes Rousses Massif), Quaternary Scie. Rev., 26, 2644-2660, https://doi.org/10.1016/j.quascirev.2007.07.007, 2007.

Hall, B. L. and Henderson, G. M.: Use of uranium-thorium dating to determine past ${ }^{14} \mathrm{C}$ reservoir effects in lakes: examples from Antarctica, Earth Planet. Sc. Lett., 193, 565-577, https://doi.org/10.1016/S0012-821X(01)00524-6, 2001.

Heinecke, L., Mischke, S., Adler, K., Barth, A., Biskaborn, B. K., Plessen, B., Nitze, I., Kuhn, G., Rajabov, I., and Herzschuh, U.: Climatic and limnological changes at Lake Karakul (Tajikistan) during the last $\sim 29$ cal ka, J. Paleolimnol., 58, 317-334, https://doi.org/10.1007/s10933-017-9980-0, 2017.

Herzschuh, U.: Palaeo-moisture evolution in monsoonal Central Asia during the last 50,000 years, Quaternary Sci. Rev., 25, 163178, https://doi.org/10.1016/j.quascirev.2005.02.006, 2006.

Hodell, D. A., Schelske, C. L., Fahnenstiel, G. L., and Robbins, L. L.: Biologically induced calcite and its isotopic composition in Lake Ontario, Limnol. Oceanogr., 43, 187-199, https://doi.org/10.4319/lo.1998.43.2.0187, 1998.

Hou, J., D'Andrea, W. J., and Liu, Z.: The influence of ${ }^{14} \mathrm{C}$ reservoir age on interpretation of paleolimnological records from the Tibetan Plateau, Quaternary Sci. Rev., 48, 67-79, https://doi.org/10.1016/j.quascirev.2012.06.008, 2012.

Huayu, L., Cunfa, Z., Mason, J., Shuangwen, Y., Hua, Z., Yali, Z., Junfeng, J., Swinehart, J., and Chengmin, W.: Holocene climatic changes revealed by aeolian deposits from the Qinghai Lake area (northeastern Qinghai-Tibetan Plateau) and possible forcing mechanisms, Holocene, 21, 297-304, https://doi.org/10.1177/0959683610378884, 2010.

Hutchinson, I., James, T. S., Reimer, P. J., Bornhold, B. D., and Clague, J. J.: Marine and limnic radiocarbon reservoir corrections for studies of late-and postglacial environments in Georgia Basin and Puget Lowland, British Columbia, Canada and Washington, USA?, Quaternary Res., 61, 193-203, https://doi.org/10.1016/j.yqres.2003.10.004, 2004.

Jarvis, A.: Hole-field seamless SRTM data, International Centre for Tropical Agriculture (CIAT), available at: http://srtm.csi.cgiar. org (last access: 30 October 2012), 2008.

Jin, L., Chen, F., Morrill, C., Otto-Bliesner, B. L., and Rosenbloom, N.: Causes of early Holocene desertification in arid central Asia, Clim. Dynam., 38, 1577-1591, https://doi.org/10.1007/s00382011-1086-1, 2011.

Jull, A. J. T., Burr, G. S., and Hodgins, G. W. L.: Radiocarbon dating, reservoir effects, and calibration, Quatern. Int., 299, 64-71, https://doi.org/10.1016/j.quaint.2012.10.028, 2013.

Kalanke, J., Mingram, J., Lauterbach, S., Usubaliev, R., and Brauer, A.: Age model and microfacies analysis results obtained from microscopic analysis of overlapping petrographic thin sections of composite sequence CHAT12 from Chatyr Kol Lake, Kyrgyzstan, PANGAEA, https://doi.org/10.1594/PANGAEA.909981, 2019.

Keaveney, E. M. and Reimer, P. J.: Understanding the variability in freshwater radiocarbon reservoir offsets: a cautionary tale, J. Archaeol. Sci., 39, 1306-1316, https://doi.org/10.1016/j.jas.2011.12.025, 2012. 
Kelts, K. and Hsü, K.: Freshwater carbonate sedimentation, in: Lakes, Springer, https://doi.org/10.1007/978-1-4757-1152-3_9, 1978.

Koppes, M., Gillespie, A. R., Burke, R. M., Thompson, S. C., and Stone, J.: Late Quaternary glaciation in the Kyrgyz Tien Shan, Quaternary Sci. Rev., 27, 846-866, https://doi.org/10.1016/j.quascirev.2008.01.009, 2008.

Kudo, A., Zheng, J., Koerner, R., Fisher, D., Santry, D., Mahara, Y., and Sugahara, M.: Global transport rates of ${ }^{137}$ Cs and ${ }^{239+}$ ${ }^{240} \mathrm{Pu}$ originating from the Nagasaki A-bomb in 1945 as determined from analysis of Canadian Arctic ice cores, J. Environ. Radioactiv., 40, 289-298, https://doi.org/10.1016/S0265931X(97)00023-4, 1998.

Lamoureux, S.: Varve Chronology Techniques, in: Tracking Environmental Change Using Lake Sediments: Basin Analysis, Coring, and Chronological Techniques, edited by: Last, W. M. and Smol, J. P., Springer Netherlands, Dordrecht, https://doi.org/10.1007/0-306-47669-X_11, 2001.

Lauterbach, S., Brauer, A., Andersen, N., Danielopol, D. L., Dulski, P., Hüls, M., Milecka, K., Namiotko, T., Obremska, M., and Von Grafenstein, U.: Environmental responses to Lateglacial climatic fluctuations recorded in the sediments of pre-Alpine Lake Mondsee (northeastern Alps), J. Quaternary Sci., 26, 253-267, https://doi.org/10.1002/jqs.1448, 2011.

Lauterbach, S., Witt, R., Plessen, B., Dulski, P., Prasad, S., Mingram, J., Gleixner, G., Hettler-Riedel, S., Stebich, M., and Schnetger, B.: Climatic imprint of the midlatitude Westerlies in the Central Tian Shan of Kyrgyzstan and teleconnections to North Atlantic climate variability during the last 6000 years, Holocene, 24, 970-984, https://doi.org/10.1177/0959683614534741, 2014.

Lauterbach, S., Mingram, J., Schettler, G., and Orunbaev, S.: Two twentieth-century MLH $=7.5$ earthquakes recorded in annually laminated lake sediments from Sary Chelek, western Tian Shan, Kyrgyzstan, Quaternary Res., 92, 288-303, https://doi.org/10.1017/qua.2019.21, 2019.

Leemann, A. and Niessen, F.: Holocene glacial activity and climatic variations in the Swiss Alps: reconstructing a continuous record from proglacial lake sediments, Holocene, 4, 259-268, https://doi.org/10.1177/095968369400400305, 1994.

Li, Y. and Morrill, C.: Multiple factors causing Holocene lakelevel change in monsoonal and arid central Asia as identified by model experiments, Clim. Dynam., 35, 1119-1132, https://doi.org/10.1007/s00382-010-0861-8, 2010.

Lockot, G., Ramisch, A., Wünnemann, B., Hartmann, K., Haberzettl, T., Chen, H., and Diekmann, B.: A Process- and Provenance-Based Attempt to Unravel Inconsistent Radiocarbon Chronologies in Lake Sediments: An Example from Lake Heihai, North Tibetan Plateau (China), Radiocarbon, 57, 10031019, https://doi.org/10.2458/azu_rc.57.18221, 2016.

Lotter, A. F. and Lemcke, G.: Methods for preparing and counting biochemical varves, Boreas, 28, 243-252, https://doi.org/10.1111/j.1502-3885.1999.tb00218.x, 1999.

MacDonald, G. M., Beukens, R. P., and Kieser, W.: Radiocarbon dating of limnic sediments: a comparative analysis and discussion, Ecology, 72, 1150-1155, https://doi.org/10.2307/1940612, 1991.

Mathis, M., Sorrel, P., Klotz, S., Huang, X., and Oberhänsli, H.: Regional vegetation patterns at lake Son Kul reveal
Holocene climatic variability in central Tien Shan (Kyrgyzstan, Central Asia), Quaternary Sci. Rev., 89, 169-185, https://doi.org/10.1016/j.quascirev.2014.01.023, 2014.

Mischke, S., Liu, C., Zhang, J., Zhang, C., Zhang, H., Jiao, P., and Plessen, B.: The world's earliest Aral-Sea type disaster: the decline of the Loulan Kingdom in the Tarim Basin, Sci. Rep., 7, 43102, https://doi.org/10.1038/srep43102, 2017.

Mischke, S., Weynell, M., Zhang, C., and Wiechert, U.: Spatial variability of ${ }^{14} \mathrm{C}$ reservoir effects in Tibetan Plateau lakes, Quatern. Int., 313-314, 147-155, https://doi.org/10.1016/j.quaint.2013.01.030, 2013.

Müller, G., Irion, G., and Förstner, U.: Formation and diagenesis of inorganic $\mathrm{Ca}-\mathrm{Mg}$ carbonates in the lacustrine environment, Naturwissenschaften, 59, 158-164, 1972.

Norris, R. S. and Arkin, W. M.: Known nuclear tests worldwide, 1945-98, B. Atom. Sci., 54, 65-68, 1998.

Ojala, A. E. K., Francus, P., Zolitschka, B., Besonen, M., and Lamoureux, S. F.: Characteristics of sedimentary varve chronologies - A review, Quaternary Sci. Rev., 43, 45-60, https://doi.org/10.1016/j.quascirev.2012.04.006, 2012.

Peck, J. A., Khosbayar, P., Fowell, S. J., Pearce, R. B., Ariunbileg, S., Hansen, B. C., and Soninkhishig, N.: Mid to Late Holocene climate change in north central Mongolia as recorded in the sediments of Lake Telmen. Palaeogeography, Palaeoclimatology, Palaeoecology, 1832, 135-153, https://doi.org/10.1016/S00310182(01)00465-5, 2002.

Potts, P. J., Thompson, M., Chenery, S. R., Webb, P. C., and Kasper, H. U.: GeoPT13-An international proficiency test for analytical geochemistry laboratories-report on round 13 July 2003 (Köln Loess), International Association of Geoanalysts, 2003.

Ramsey, C. B.: Bayesian analysis of radiocarbon dates, Radiocarbon, 51, 337-360, https://doi.org/10.1017/S0033822200033865, 2009.

Rasmussen, K., Ricketts, R., Johnson, T., Romanovsky, V., and Grigina, O.: An 11,000-year history of Central Asian paleoclimate change recorded in deep sediments of Lake Issyk-Kul, Kyrgyzstan, Eos Trans. AGU, 81, 2000.

Reference Book of Climate USSR, Kyrgyz SSR: HydrometeoPublishing, V. 18, 19, 31, 32. Parts 1, 2, 4, Hydrometeo Publishing, Leningrad; 289, 1988 (in Russian).

Reimer, P. J., Bard, E., Bayliss, A., Beck, J. W., Blackwell, P. G., Ramsey, C. B., Buck, C. E., Cheng, H., Edwards, R. L., and Friedrich, M.: IntCal13 and Marine13 radiocarbon age calibration curves 0-50,000 years cal BP, Radiocarbon, 55, 1869-1887, https://doi.org/10.2458/azu_js_rc.55.16947, 2013.

Ricketts, R. D., Johnson, T. C., Brown, E. T., Rasmussen, K. A., and Romanovsky, V. V.: The Holocene paleolimnology of Lake Issyk-Kul, Kyrgyzstan: trace element and stable isotope composition of ostracodes, Palaeogeogr. Palaeocl., 176, 207-227, https://doi.org/10.1016/S0031-0182(01)00339-X, 2001.

Romanovsky, V. V. (Ed.): Climate, Glaciers, Lakes of the TienShan: a journey to the past, The Institute of Water Problems and Hydropower, Ilim,Bishkek, Kyrgyzstan, 168 pp., ISBN:9789967012-032-7, 2007.

Schettler, G., Mingram, J., Negendank, J. F. W., and Jiaqi, L.: Palaeovariations in the East-Asian Monsoon Regime Geochemically Recorded in Varved Sediments of Lake Sihailongwan (Northeast China, Jilin Province). Part 2: a 200Year Record of Atmospheric Lead-210 Flux Variations and 
its Palaeoclimatic Implications, J. Paleolimnol., 35, 271-288, https://doi.org/10.1007/s10933-005-0102-z, 2006.

Schroeter, N., Lauterbach, S., Stebich, M., Kalanke, J., Mingram, J., Yildiz, C., Schouten, S., and Gleixner, G.: Biomolecular Evidence of Early Human Occupation of a High-Altitude Site in Western Central Asia During the Holocene, Front. Earth Sci., 8, 20 pp., https://doi.org/10.3389/feart.2020.00020, 2020.

Schwarz, A., Turner, F., Lauterbach, S., Plessen, B., Krahn, K. J., Glodniok, S., Mischke, S., Stebich, M., Witt, R., and Mingram, J.: Mid-to late Holocene climate-driven regime shifts inferred from diatom, ostracod and stable isotope records from Lake Son Kol (Central Tian Shan, Kyrgyzstan), Quaternary Sci. Rev., 177, 340-356, https://doi.org/10.1016/j.quascirev.2017.10.009, 2017.

Shapley, M. D., Ito, E., and Donovan, J. J.: Authigenic calcium carbonate flux in groundwater-controlled lakes: implications for lacustrine paleoclimate records, Geochim. Cosmochim. Ac., 69, 2517-2533, https://doi.org/10.1016/j.gca.2004.12.001, 2005.

Shnitnikov, A. V., Lijva, A. A., Berdovskaya, G. N., and Sevastyanov, D. V.: Paleolimnology of Chatyrkel Lake (Tien-Shan), Polskie Archiwum Hydrobiologii, 25, 383-390, 1978.

Sidorov, D. A.: Two new species of freshwater amphipods (Crustacea: Gammaridae) from Central Asia, with comments on the unusual upper lip morphology, Zootaxa, 3317, 1-24, https://doi.org/10.11646/zootaxa.3317.1.1, 2012.

Taft, J. B., Phillippe, L. R., Dietrich, C. H., and Robertson, K. R.: Grassland composition, structure, and diversity patterns along major environmental gradients in the Central Tien Shan, Plant Ecol., 212, 1349-1361, https://doi.org/10.1007/s11258011-9911-5, 2011.
Turner, T. E., Swindles, G. T., Charman, D. J., Langdon, P. G., Morris, P. J., Booth, R. K., Parry, L. E., and Nichols, J. E.: Solar cycles or random processes? Evaluating solar variability in Holocene climate records, Sci. Rep., 6, 23961, https://doi.org/10.1038/srep23961, 2016.

Williams, M. and Konovalov, V.: Central Asia temperature and precipitation data, 1879-2003, Boulder, Colorado: USA National Snow and Ice Data Center, 2008.

Wolff, C., Plessen, B., Dudashvilli, A. S., Breitenbach, S. F., Cheng, H., Edwards, L. R., and Strecker, M. R.: Precipitation evolution of Central Asia during the last 5000 years, Holocene, 27, 142154, https://doi.org/10.1177/0959683616652711, 2017.

Żarczyński, M., Tylmann, W., and Goslar, T.: Multiple varve chronologies for the last 2000 years from the sediments of Lake Żabińskie (northeastern Poland) - Comparison of strategies for varve counting and uncertainty estimations, Quat. Geochronol., 47, 107-119, https://doi.org/10.1016/j.quageo.2018.06.001, 2018.

Zhou, A., Chen, F., Qiang, M., Yang, M., and Zhang, J.: The discovery of annually laminated sediments (varves) from shallow Sugan Lake in inland arid China and their paleoclimatic significance, Sci. China Ser. D, 50, 1218-1224, https://doi.org/10.1007/s11430-007-0081-1, 2007.

Zolitschka, B., Francus, P., Ojala, A. E. K., and Schimmelmann, A.: Varves in lake sediments - a review, Quaternary Sci. Rev., 117, 1-41, https://doi.org/10.1016/j.quascirev.2015.03.019, 2015. 